\title{
Review the Extent and Cause of Post Harvest Loss of Fruits and Vegetables in Ethiopia
}

\author{
Melkamu Workineh ${ }^{1} \quad$ Melkamu Enyew ${ }^{2}$ \\ 1.Debre markos university, College of agriculture and Natural Resource, department of Horticulture \\ (Horticulture) \\ 2.Debre markos university, Burie campus, department of Plant science (Plant breeding)
}

\begin{abstract}
Horticulture is an important sector for economic development and contributes to increased food security and improves the populations' nutrition intake. Horticultural crop production (Fruits and vegetables) is the major farming system in Ethiopia and farmers have willingness to increase the production and productivity of the crops even if it faces many challenges. Post-harvest loss of fruit and vegetable is a matter of great economic concern in agriculture. The post-harvest systems covers the period that runs from exit from the field to the time of consumption.Post-harvest loss is a global problem but it is more critical in developing countries. Post-harvest losses can be measured both by quality and quantity losses. The major causes of postharvest losses can be classified into direct /primary (technical origin) and indirect /secondary (socio economic origin) factors. The extent of post-harvest losses may vary greatly among commodities, production areas, season of production, ways of handling, management practices and economic status of the country. Higher postharvest losses not only reduce the availability of fruits but also result in increase in per unit prices of the produce and thus limit the accessibility by the majority of community segments. Postharvest loss as going beyond the loss of the actual crop to include loss in the environment, resources, labor needed to produce the crop and livelihood of the individual involved in the production process. Currently there are limited literatures to review on the cause and extent of postharvest losses of fresh fruits and vegetables in Ethiopia due to lack of research works in the sector. Although, it is possible to estimate such losses of perishables horticultural commodity based on the annual production data of central statistics agency (CSA) and food and agricultural organization of the country (FAO). It is too early to reach a conclusive recommendation since limited study were conducted in the cause and extent of post harvest loss of horticultural crops. Hence, further studies must be done to tackle the cause of post harvest loss of horticultural crops and minimized the extent of post harvest losses.
\end{abstract}

Keywords: Post harvest loss, cause, extent

DOI: $10.7176 / \mathrm{JBAH} / 11-13-01$

Publication date:July $31^{\text {st }} 2021$

\section{INTRODUCTION}

Agriculture is the mainstay of the Ethiopian economy (Bezabih and Hadera, 2007). Promote agricultural growth is a great demand for investment and progress in the agricultural sector in many developing countries (FAO et al., 2012). The country has highly diversified agro-ecological conditions for the production of different horticultural crops (Bekele, 1989; Milaku, 2005). More than $85 \%$ of its population is engaged in small scale agricultural production as a major means of livelihood. Food availability and accessibility can be increased by increasing production, improving distribution and reducing the losses. Horticulture can be an important sector for economic development and contribute to increased food security and improve the populations' nutrition intake (Weinberger \& Lumpkin, 2007). Thus, reduction of post-harvest food losses is a critical component of ensuring future global food security (Bekele, 1989; Fantahun and Williamson, 2001; Bezabih and Hadera, 2007).

The Ministry of Agriculture and Rural Development focuses on market-led agricultural development and the government pledges support to market integration and agro enterprise development. Horticultural crop production in Ethiopia faces many challenges even though farmers have willingness to increase the production and productivity of the crops. Farmers needed to produce potential fruits and vegetables for marketing and consumption, i.e., they have a comparative advantage to generate income as compared to cereals, and especially vegetables require shorter time for production, yield more and generate higher income and the market outlet (MOARD, 2005).

Horticultural crop production (Fruits and vegetables) is the major farming system in Ethiopia. Particularly in the areas where water is available and farmers have access to the market, horticultural production is used as a major source of cash income for households (Milaku, 2005; Bezabih and Hadera, 2007).The growing population and changing dietary habits in Ethiopia has increased the demand for fruit (ILRI, 2011). Especially the demand for local fruits with higher quality for example mango, papaya, apple and avocado are emerging. The fruit production in Ethiopia has been small compared to other crops but it has a great potential since the climate is favorable for many horticulture products (Berhel et al., 2010).

Post-harvest loss of fruit and vegetable is a matter of great economic concern in agriculture. Post-harvest 
loss could be rightly stated as the qualitative and quantitative loss of horticultural produce at any moment along the post harvest chain which includes the change in the edibility and wholesomeness i.e. quality of the produce finally preventing its consumption. Produce after harvesting undergoes a number of processes including transportation and storage under various environmental conditions. Although time, human force, money and material resources are devoted for planting, irrigation, fertilizer application, $50 \%$ of horticultural crops are lost due to post-harvest loss (Saxena et al., 1990; Alazar, 2007; Olayemi et al., 2010).

Post-harvest losses vary greatly across commodity types, with production areas and the season of production. Even though only limited studies were conducted in Ethiopia, post-harvest loss and quality deterioration of horticultural crops are estimated to be $25-40 \%$ (Yohannes, 1989). Post-harvest losses and quality deterioration of horticultural crops are mostly caused by pests, microbial infection, mechanical injury, physical damage ; physiological and environmental conditions such as heat, drought and inappropriate postharvest handling (Alazar, 2007; Idah et al., 2007; Olayemi et al., 2010).

In Ethiopia limited post-harvest improvement studies have been carried out for locally consumed fruits and vegetables. However, fruits such as banana, orange, lemon, pineapple and avocado which exported to Arab countries, Europe and the Middle East are relatively graded and packaged appropriately (Alazar, 2007). That is why we are initiating to review the causes which accelerated post harvest losses of fruits and vegetables, and review the extent of post harvest losses of fruits and vegetables.

\section{MAIN BODY}

\subsection{Post harvest system}

Post-harvest system encompasses from crop harvesting to crop consumption with minimum loss and maximum efficiency and return for all involved (Hodges et al., 2011). The post-harvest covers the period that runs from exit from the field to the time of culinary preparation (Kumar and Pankaj, 2010). Standards of quality and consumer preferences and purchasing power vary greatly among countries and cultures.

Post-harvest loss exists throughout the supply chain, from initial agricultural production down to final household consumption (Parfitt et al., 2010). Losses of food from farm to table through storage, transport, processing, and retail and in consumption are huge (Lundq vist et al., 2008).

\subsection{Post Harvest Losses}

Post-harvest loss is a global problem but it is more critical in developing countries. The food and agriculture organization of the United Nations (FAO) estimated that one-third of food produced for human consumption is wasted globally, which is equivalent to about 1.3 billion tons per year. This loss leads to significant losses of resource used for food production (FAO, 2011).

Food loss and food waste add to contribute to post-harvest food losses. Food loss refers to total modification or decrease of food quantity or quality which makes it unfit for human consumption (Kumar and Pankaj, 2010). Food waste can occur at different points of food supply chain (Parfitt et al., 2010) and this wastage has a significant influence on the sub-Saharan African situation of food shortage (Affognon et al., 2015). Food waste is a subset or sub-category of the food losses (Buzby and Hyman, 2012). According to Buzby et al (2010) food waste occurs when the an edible food item goes unutilized as a result of human action or inaction and is often the result of a decision made farm-to-fork by businesses, governments and farmers (Buzby and Hyman, 2012).

Food waste and loss is an enormous issue worldwide. The world is producing more than enough food, but a vast amount of what is produced gets lost on its way from the field to the consumer. That is why Hunger is still one of the most urgent development challenges in different developing countries (FAO, 2015). According to the FAO, about $45 \%$ of fruits and vegetables and $45 \%$ of roots and tubers are lost or wasted. This is one-third of all the food produced for human consumption (FAO, 2015).

Postharvest losses originate from poor pre-harvest and postharvest management including bad handling of produce during transit and storage leading to partial or total loss in produce quality (Prusky, 2011). A postharvest loss in general term for all the wastage of resources that goes into the production and harvesting of farm produce. These include the land, labor, energy, water, fertilizer and so forth (James and Zikankuba, 2017). Post harvest loss implies the decrease in the quantity or quality of products which was originally intended for human consumption (FAO, 2013).

Post harvest loss of agricultural produce is experienced in Ethiopia, most especially in perishable horticultural commodities like fruits (mango, banana, papaya, avocado, sweet orange etc.) and vegetables (Getachew, 2004). Post-harvest losses can be measured both by quality and quantity losses. The losses can appear in any stage during activities such as harvesting, transportation, packing, at market places and preparation before consumption (Ladaniya, 2008; Adeoye, 2009; Kader, 2009; Buyukbay et al., 2010; Hodges et al., 2011; Buzby et al, 2014; Kiaya, 2014). It occurs throughout the value chain, as a result of technical and managerial setbacks during harvest, handling, transportation, processing, packaging, marketing and distribution (FAO, 2016). 


\subsubsection{Quantitative post harvest loss}

Quantitative food loss can be defined as reduction in weight of edible horticultural commodity available for human consumption. Quantitative post harvest loss or physical loss as measured by decreased weight or volume (Rahman, 2007; Kumar and Pankaj, 2010; Hodges et al., 2011; Buzby and Hyman, 2012; FAO, 2014). The quantitative loss is come due to factors such as spillage, consumption by pest and also due to physical changes in temperature, moisture content and chemical changes (FAO, 1980).

The quantitative losses are very easy to measure in developing countries (Humble and Reneby, 2014). Postharvest losses reduce the availability of food crops and income that could be generated by selling these products, thus in terms of quantity are linked to food security (FAO and World Bank, 2010; Jayne et al., 2010; Hodges et al., 2011).

\subsubsection{Qualitative post harvest loss}

Qualitative losses such as loss in edibility, nutritional quality, caloric value, wholesomeness and consumer acceptability (unwanted changes to taste, color, texture or cosmetic features of food) of the horticultural commodity and much more difficult to assess and measure (Dorais et al., 2001; Kader \& Rolle, 2004; Kader, 2005; Adeoye, 2009; Buyukbay et al., 2010; Buyukbay et al., 2011; Buzby and Hyman, 2012). The qualitative losses are related directly to nutritional and they are more complicated to measure (Humble and Reneby, 2014). Qualitative deterioration makes food unfit for human consumption and is rejected, this contributes to post harvest food loss (Kumar and Pankaj, 2010; Aulakh et al, 2013). In most cases, the quality deterioration goes along with a significant loss of nutritional value, which might affect the health and nutrition status of the whole community (FAO, 2014).

Standards of quality, consumer preferences and purchasing power vary greatly among countries and cultures. Elimination of defects from a given commodity before marketing is much less rigorous in developing countries than in developed countries. However, this is good, because appearance quality is often overemphasized in developed countries (Kader, 2005). Downgrade in quality leads to loss of consumer appeal and is frequently described by comparison with locally accepted standards for premium quality such as appearance, taste, texture and nutritional value. Losses in quality are evidenced by a decrease in the market value of the product (Flores, 2000; Ward \& Jeffries, 2000; Ladaniya, 2008).

\subsection{Cause of post harvest loss}

The main causes of post-harvest loss in low-income countries may include improper methods of harvesting, insufficient cooling and unhygienic handling, lack of infrastructure, poor technical and managerial skill in food production and post-harvest (FAO, 2011). Bio-deterioration by microorganisms, insects, rodents or birds is also the main causes of postharvest loss in low-income countries (Hodges et al., 2011).

Ethiopia's Ministry of Agriculture is striving to minimize post-harvest losses, which is causing up to 20$40 \%$ losses in sub-Saharan Africa (FAO, 2009). The post-harvest losses of perishable (vegetable and fruits) food crops amounted to be about 30\% (Fekadu and Dandena , 2006) due to the presence of high moisture content (65$95 \%$ ), insect infestation and damage during post-harvest handling techniques (packaging, storage and transportation).

According to FAO (2011) factors affecting post-harvest food losses of perishables vary widely from place to place and become more and more complex as systems of marketing become more complex. The major causes of postharvest losses can be classified into direct /primary (technical origin) and indirect /secondary (socio economic origin) factors (Kader, 2002, Yahaya, 2005; Sudheer \& Indira, 2007). Both the primary and secondary factors contribute to physiological deterioration, mechanical damage, biological and microbiological spoilage of fresh produce.

\subsubsection{Primary Causes of post harvest Loss}

A large portion of fresh fruits were lost worldwide after harvest. The main causes physiological (wilting, shriveling and chilling injury, etc), microbiological (decay due to fungi and Bacteria) biological, physical and mechanical injury. These causes, in most instances can be interrelated, that is mechanical injury can lead to postharvest decay in many cases (FAO, 1989; Kader, 2005; Adeoye et al., 2009; Olayemi et al., 2010; Parfitt et al., 2010; Madrid, 2011; Ukech and Chiejina, 2012; Etebu et al., 2013).

Causes of post harvest loss can complement each other. Damage caused by microorganisms is nearly always preceded by mechanical, chemical and or physical damage, thereby weakening the products natural defences, and facilitating attacks by fungi, bacteria or moulds (Sudheer \& Indira, 2007). In addition, other factors such as insect and mite injury, diseases which occur due to non-infectious pathogens and pathological rots also cause post-harvest loss of fruits and vegetables. However, among the causes, the pathological rots are the most serious which is followed by mechanical injury. Pathological rots in combination with mechanical damage cause serious damage to the perishables (Elias et al, 2010; FAO, 2011).

Environmental factors such as temperature, relative humidity and oxygen concentration most especially during storage are also greatly responsible for damage by microorganisms. Environmental conditions such as 
temperature and humidity are responsible for rendering fruits and vegetables susceptible for pathological attacks. However, the loss of fruits and vegetables due to physiological and biochemical damage are closely interrelated (Sani and Alao, 2006).

\subsubsection{Microbiological}

Fruits and vegetable are susceptible to attack by bacteria and fungi, with pathological breakdown. All living material is subject to attack by parasites. Fresh produce can become infected before or after harvest by diseases widespread in the air, soil and water. Some disease is able to penetrate the unbroken skin of produce; others require an injury in order to cause infection. The succulent nature of fruits and vegetables makes them easily invaded by these organisms. Damage so produced is probably the major cause of loss of fresh produce (Elias et al., 2010; Kader, 2013).

Serious post-harvest diseases occur rapidly and may cause extensive break down of the commodity, sometimes spoiling the entire package (Mustapha and Yahaya, 2006; Yahaya , 2005). Pathological losses of vegetables are caused by microbial spoilage organisms such as fungi, bacteria, yeasts and moulds. Common rot causing pathogens in vegetables include fungal strains such as Alternaria, Botrytis, Diplodia, Rhizopus, Pencillium and Fusarium, and among bacteria Erwinia and Pseudomonas cause extensive damage (Sudheer \& Indira, 2007). Vegetables are prone to disease attack by these organisms because of their succulent nature. Postharvest diseases can cause extensive commodity breakdown, sometimes spoiling the entire package. At least $36 \%$ of vegetable decay is caused by soft rot bacteria, with the source of infection coming from the field; surface cleaning water, contact equipment and storage environment. High temperature and relative humidity favour the development of post-harvest decay organisms. While more acidic tissue is generally attacked by fungi, but fruits and vegetables with pH above 4.5 are mainly attacked by bacteria (Opadokun, 1987, Kader, 2002; Sudheer \& Indira, 2007; Munhuweyi, 2012).

Horticultural crops can be contaminated with different microbial and chemical contaminants during handling and processing and become source for infectious microorganisms (Moy, 2005).

In apple and tomato fruits, Penicillium expansum infection caused reduction in the molecular mass of hemicelluloses, particularly in the xyloglucan. Hemicellulose degradation is important in the breakdown of plant cell walls, causing cell wall loosening, increasing the porosity of the wall and allowing the colonization of plant tissue (Miedes and Lorences, 2004).

The harvested produce might have been infected by pathogens prior to harvest under field conditions or they may get infected during transit and storage. Fruits and vegetables are considered as the perishable crops than cereal, pulses and oil seed crops. Most of them contain very high moisture content (about 70 - $95 \%$ water), usually have large size $(5 \mathrm{~g}-5 \mathrm{~kg})$, exhibit higher respiration rate and usually have soft texture, which favour the growth and development of several diseases by the microorganisms between harvest and consumption (Sharma et al., 2009).

Agrios (2005) reported that Postharvest diseases destroy 10 to $30 \%$ of the total yield of crops, and in some perishable crops, especially in developing countries, they destroy more than $30 \%$ of the crop yields. Especially fresh fruits and vegetables are highly perishable products; and their quality is affected by postharvest handling, transportation, storage and marketing. The improper handling, packaging, storage and transportation may result in decay and production of microorganisms which become activated because of the changing physiological state of the fruits and vegetables (Wilson et al., 1995).

Fungi are the most important and prevalent pathogens infecting a wide range of host plants and causing destructive and economically important losses of most fresh fruits and vegetables during storage and transportation (Sommer, 1985). Fruit, due to their low pH, higher moisture content and nutrient composition are very susceptible to attack by pathogenic fungi, which in addition to causing rots may also make them unfit for consumption by producing mycotoxins (Moss, 2002).

Micro organisms cause damage to stored foods (e.g., fungi and bacteria). Micro-organisms usually directly consume small amount of the food but they damage the food to the point that it becomes unacceptable because of rotting or other defects. Toxic substances elaborated by molds (known as mycotoxins), cause some food to be condemned and hence lost. The best known mycotoxins is aflatoxin (a liver carcinogen), which is produced by the mold Aspergillus flavus. Another mycotoxin which is found in some processed apple and pear products is patulin, which is formed in the apple by rotting organisms such as Penicillium expansum which infect fresh apples before they are processed (Atanda et al.,2011).

\subsubsection{Mechanical}

Fresh horticultural crops are diverse in morphological structure (roots, stems, leaves, flowers, fruits, and so on), composition and general physiology. Thus, commodity requirements and recommendations for maximum postharvest life vary among the commodities. All fresh horticultural crops are high in water content and are subject to desiccation (wilting, shriveling) and mechanical injury (Kader, 2013). Mechanical factors refer to the inappropriate ways of handling agricultural produce in all the value chain processes from harvesting to storage. It involves the ruthless, careless and rough handling of the agricultural produce (Antunes et al., 2007) that exposes 
them to all forms of bruises, cracks, peeling of surfaces and soft textures of fruits, cuts, abrasion, scuffing and scratches (Munhuweyi, 2012).

Mechanical damage can arise from careless and rough handling of vegetables during harvesting, packaging, transportation and storage. There are three main mechanisms of mechanical damage, namely vibration, compression and impact damage. These cause mechanical damage in the form of cuts, cracks, punctures, abrasion, scuffing and scratches with the predominant form being bruising (the darkened area visible under the surface of many vegetables and fruits). Bruising usually detracts from the quality of the produce and may decay (Bollen, 2006; Opara, 2007). Bruising renders the product unsalable to most people although it usually has minor effect upon the nutritional value. The skin of horticultural products is an effective barrier to most of the opportunistic bacteria and fungi that cause rotting of the tissues. Breaking of the skin also stimulates physiological deterioration and dehydration (Atanda, 2011).

Mechanically injured vegetable produce is more prone to attack by biological and microbiological spoilage organisms. Presence of mechanical injuries increases rate of water loss and respiration activity in vegetables, leading to rapid quality loss. Processing operations such as spoilage, abrasion, excessive polishing, peeling and trimming can also add to loss of commodity (Hodges et al., 2011). Mechanical damage during harvest can become a serious problem by disposing it to decay, increasing water loss, respiration and ethylene production rates which leads to deterioration (Kitinoja and Kader, 2002). Bruises and other mechanical damage affect appearance and also provide entrance to decaying organisms (Olayemi et al., 2010). Some insects and birds are also responsible for the mechanical injury in fruits and vegetables (Mustapha and Yahaya, 2006; Hayatu, 2000) and (Yahaya , 2005). Mechanical injuries like bruising and cracking of fruits and vegetables render them more prone to attack by organisms and this increase the rate of water loss and gaseous exchange. Several tines the damage cause by mechanical injury on fruits and vegetables as a result of pressure thrust during transportation, though many times invisible, but causes rupturing of inner tissues and cells. Such produce is degraded faster during the natural ageing process (Mustapha and Yahaya, 2006 ; Yahaya, 2005).

Cuts of horticultural commodity can lead to transitory increases in respiration, ethylene production, phenolics production and cell deterioration near the site of the injury (Toivonen, 2005). Several factors influence the severity and size of bruising sustained, including maturity, water potential, tissue or cellular orientation at the site of the injury, shape of the object imparting the bruising force, energy and angle of the impact and temperature of the product (Miller, 2003 ). Cut type injuries are most prevalent in fresh-cut fruit and vegetable products. Severity of response to cutting is very much dependant on the tissue characteristics, maturity of the fruit or vegetable of interest, the coarseness or sharpness of the cutting implement used and the temperature at which the cutting is done. Cut injuries occur during the harvest process of many fruits and vegetables and is more severe in machine-harvested as compared with hand-harvested product.

Mechanical injuries make agricultural produce susceptible to the pathological and microbial attack through the openings in the skins of the produce, speeding up the rotting of the fruit, crop and vegetable tissues (Atanda et al., 2011).This undesirable condition generally leads to considerable quality post-harvest losses (Arah et al., 2016).Sadly, mechanical injuries on agricultural produce intensify the rate of water loss as well as respiration activities resulting in a greater percentage of quality loss (Munhuweyi, 2012). Bruising, cutting' excessive pooling or trimming of horticultural products are causes of loss (Atanda et al., 2011).

The possibility of fruits and vegetables encountering maximum mechanical damage during harvesting is very possible if proper means of picking, harvesting, transportation, storage, marketing etc. are not adopted. Therefore, large quantity of tuber and root crops like potato, sweet potato, etc. becomes damage and unmarketable due to faulty methods of digging them out. In fruits like apples, it has soft outer skins which are highly prone to mechanical damage (Mustapha and Yahaya, 2006; Yahaya , 2005). Gradually the quality of fruits deteriorates and the produce fetches lesser prices in the market. The processing operations such as spillage, abrasion, excessive polishing, peeling and trimming add to the loss of commodity. Puncturing of the containers and defective seals also leads to mechanical injury (Mustapha and Yahaya, 2006; Yahaya, 2005).

\subsubsection{Physiological}

Natural respiratory losses which occur in all living organisms account for a significant level of weight loss and moreover, the process generates heat. Certain physiological changes which occur during ripening, senescence, including wilting and termination of dormancy (e.g., sprouting) may increase the susceptibility of the commodity to mechanical damage or infection by pathogens ( Nunes, 2008; Babita \& Kiranmayi, 2010). A reduction in nutritional level and consumer acceptance may also arise with these changes. Production of ethylene results in premature ripening of certain crops. Abnormal physiological deterioration occurs when fresh produce is subjected to extremes of temperature, of atmospheric modification or contamination. This may cause unpalatable flavours, failure to ripen or other changes in the living processes of the produce, making it unfit for use (Atanda et al., 2011).

The natural respiratory losses of agricultural produce can affect the normal functioning such as loss of weight (Atanda et al., 2011) and an increase in the rate of natural deterioration. This condition is often 
engineered by high temperature, mechanical injury and low atmospheric humidity. It results in quality postharvest losses in the vitamin content (Munhuweyi, 2012), the production of ethylene that leads to premature ripening of some agricultural produce (Atanda et al., 2011) and unpalatable flavors of agricultural produce that affect its marketing as well as patronage by consumers. Water soaking developed during the late stages of fruit ripening. Gel breakdown in inner mesocarp tissue of plums was associated with high viscosities of water-soluble pectin with low levels of extractable juice (Negi and Handa, 2008).

Horticultural crops may be characterized as being either climacteric or non-climacteric, depending on their respiratory pattern. Climacteric fruits can be harvested when mature but before the onset of ripening. After the climacteric, the respiration rate slows down as the fruit ripens and develops quality (Sirivatanapa, 2006). Thus, in the present study the harvesting of mandarin without proper maturity will lead to post-harvest loss and quality deterioration.

Physiological deterioration of vegetables refers to aging of products during storage due to natural reactions (Flores, 2000). It may be subdivided into the normal and the abnormal. The former covers respiratory losses that take place in all living materials; the decline in vitamin content and transpiratory or wilting losses of water. Abnormal physiological losses arise for example from exposure to extremes of heat or cold or otherwise unsuitable environmental conditions (Barbosa-Cánovas et al., 2003). Examples include freezing injury, chilling injury and sunburn (Kader, 1983) which causes a yellow or bronze discolouration when fruit surface temperatures reach $46-49^{\circ} \mathrm{C}$ in the presence of direct light (Wand et al., 2005).

\subsubsection{Biological}

The rate of biological deterioration depends on several environmental (external) factors, including temperature, relative humidity, air velocity and atmospheric composition (concentrations of oxygen, carbon dioxide and ethylene) and sanitation procedures (Kitinoja and Gorny, 1999; Kader, 2002; Gross et al, 2000; Bartz and Brecht, 2002; Kader, 2013).

Consumption of food by rodents, birds, monkeys and other large animals causes direct disappearance of food. Sometimes the level of contamination of food by the excreta, hair and feathers of animals and birds is so high that the food is condemned for human consumption. Insects cause both weight losses through consumption of the food and quality losses because of their frass, webbing, excreta, heating and unpleasant odours that they can impart to food (Atanda et al., 2011, Helvetas, 2014).

\subsubsection{Chemical}

The chemical constituents in stored agricultural produce undergo spontaneous reaction that causes loss in their sensory qualities such as colour, flavor, texture and nutritional value (Kiaya, 2014). Many of the chemical constituents naturally present in stored foods spontaneously react causing loses of colour, flavour, texture and nutritional value. One such reaction is the "maillard reaction" that causes browning and decolouration in dried fruits and vegetables. This chemical reaction is highly triggered by exposure of agricultural produce to high temperatures and exposure to the high radiation of sunlight. Also, high application of chemical fertilizers and chemical pesticides can equally result in postharvest losses. There can also be accidental or deliberate contamination of food with harmful chemicals such as pesticides or obnoxious chemicals such as lubricating oil (Atanda et al., 2011). Postharvest losses of vegetables can also be as result of contamination by noxious substances including pesticides during handling. Chemical deterioration caused by chemical or biochemical agents can lead to significant losses in nutritional value and production of undesirable components e.g. rancidity in fats and oils and Maillard reactions of sugars (Kader, 2002).

\subsubsection{Biochemical reactions}

A number of enzyme-activated reactions can occur in foods in storage giving rise to off-flavors, discoloration and softening. A number of enzyme-activated reactions can occur in foods in storage giving rise to off-flavours, discolouration and softening. The problem is the unpleasant flavours that develop in frozen vegetables that have not been blanched to inactivate these enzymes before freezing (Atanda et al., 2011).

\subsubsection{Physical}

Excessive or insufficient heat or cold can spoil foods. Improper atmosphere in closely confined storage at times causes losses. Postharvest losses in nutritional quality, particularly Vitamin C content, can be substantial and are enhanced by physical damage, extended storage duration, high temperatures, low relative humidity and chilling injury of chilling-sensitive commodities (Kader, 2013). Excessive or insufficient heat or cold can spoil foods. Improper atmosphere in closely confined storage at times causes losses (Atanda et al., 2011).

\subsubsection{Secondary Causes of Post Harvest Loss}

Secondary causes of post harvest losses that encourage a primary cause of loss. They are usually the result of inadequate or non-assistant capital expenditures, technology and quality control. Market distance, duration of transport, storage condition, storage duration, duration of ripening, ripening room types, means of transport and experience in horticultural produce marketing as important determinants of the postharvest loss of commodity in Ethiopia (Zenebe et al. ,2015).

Factors that contribute to food loss range from mechanization of practices such as harvesting to handling, 
processing and others, to weather conditions, production practices, management decisions, transportation facilities, grading issues, infrastructure, consumer preferences, attitudes, and availability of financial markets. A typical post-harvest chain comprises of a number of stages for the movement of harvested output from the field to the final retail market. The losses incurred at each step vary depending upon the organization and technologies used in the food supply chain. For example, in less developed countries where the supply chain is less mechanized, larger losses are incurred during drying, storage, processing and in transportation (Madrid, 2011).

The environmental factors such as temperature, humidity, composition and proportion of gases in controlled atmospheric storage play an important role in post-harvest loss of fruits and vegetables. The high temperature and relative humidity favour the growth of micro-organisms which result in serious damage to the produce (Danladi, 2000). The effects of temperature and relative humidity are mainly comparable and interrelated because the capacity of air to hold moisture varies with the temperature. The aeration in the storage containers or in stores has its bearing on $\mathrm{RH}$ and hence indirectly on disease development. The effects of high $\mathrm{RH}$ on decay is also closely related with the effects of temperature and for many fruits and vegetables, relative humidity near saturation results in lower decay losses only if the temperature is near $0^{\circ} \mathrm{C}$ (Danladi, 2000).

\subsubsection{Improper Harvesting}

Improper harvesting practices result in loss due to spoilage of the produce before reaching to consumers along with the loss in quality of the produce such as deterioration in appearance, taste and nutritional value (Devkota $e t$ al., 2014). For fruit and vegetables, ripening at harvest time is the main factor that determines the product quality and the shelf life. However, some farmers can harvest immature crops due to economic reasons. Un-ripened fruits are more susceptible to mechanical damage and deterioration and they may have poor qualities such as high acidity and low sugar through the ripening. On the contrary, over-ripe fruits have a low shelf life. In both cases (over ripening and under ripening), fruits are more susceptible to physiological disorders. Early harvesting reduces the nutritional and economic value of crops. In some cases, whole products can be lost because they are not suitable for consumption (Kader, 1995; Azabağaoğlu, 2018).

Harvest techniques can also cause losses (Kasso \& Bekele, 2016). At the same time, farmers may not have storage containers at the harvesting or after harvesting stages. This leads to mechanical damage during harvesting of fruits, vegetables and root and tuber plants, resulting in certain losses. Inadequate methods in harvesting result in favorable conditions for secondary causes of loss. Also, inadequate harvesting equipments and rough handling during harvesting results in bruising and increase possibilities of contact of the produce with the soil which may leads to contamination with micro-organisms (Yahaya ,2005). Also extended time taken for harvesting and grading in field exposes the fruits and vegetables with field heat for longer period of time which may subsequently causes faster senescence and reduces shelf life.

During the harvesting period; incorrect estimation of harvesting time, harvesting at the wrong time, improper application of harvesting practices, failure to apply pre-cooling to fruits like cherries cause the loss in the harvesting period (4-12\%) (Özdemir et al., 2003; Özcan, 2010). In addition, the use of improper machinery and equipment's in mechanical harvesting cause serious losses. For example, mechanical harvesting of tomato has been reported to result in more cracking (33\%) than hand picking $(10 \%)$. While harvesting of fruits and vegetables during rain or immediately after rains creates conditions favorable for decay organisms. But harvesting during hotter part of the day results in faster senescence, shrivelling and wilting of fruits and vegetables as compared to produce harvested in the early morning or later afternoon (Yahaya ,2005).

\subsubsection{Inappropriate environmental Factors}

Climatic or environmental factors are seen as the most influential and important element that affects post-harvest losses (Kader \& Rolle, 2004). These factors include temperature, light intensity, humidity and the proportion and composition of aeration gases, with temperature being the leading determinant factor of the time span of perishable agricultural produce (Antunes et al., 2007).

\subsection{Improper Temperature management}

Temperature in both extremes is the main causative agent in affecting the postharvest period of horticultural perishables. Thus, amount of temperature in the horticultural produce during harvesting, handling, transport and marketing is much higher than those recommended for quality maintenance of the produce due to continuous and high rate of respiration and other related biochemical reactions of the produces (Kitinoja and AlHassan, 2012).

Temperature is the most important factor that influences deterioration of freshly harvested produce (Ladaniya, 2008). According to Kader (2013) temperature is the most important environmental factor that influences the deterioration of harvested commodities. Most perishable horticultural commodities have an optimal shelf-life at temperatures of approximately $0{ }^{\circ} \mathrm{C}$. The rate of deterioration of perishables however increases two to three-fold with every $10{ }^{\circ} \mathrm{C}$ increase in temperature. Temperature has a significant effect on how other internal and external factors influence the commodity and dramatically affects spore germination and the growth of pathogens. Temperatures either above or below the optimal range for fresh produce can cause rapid deterioration (Kader, 2002). 


\subsection{High temperature}

High temperature conditions are injurious to perishable crops. Transpiration is vital to maintaining optimal growth temperatures in growing plants. Organs removed from the plant, however, lack the protective effects of transpiration and direct sources of heat, such as sunlight, can rapidly elevate the temperature of tissues to above the thermal death point of their cells, leading to localized bleaching, necrosis (sunburn or sunscald) or general collapse (Kader, 2013).

High temperatures are well known to result in increased rates of respiration, deterioration and water loss in fresh produce, leading to reduced market value and decreased nutritional value (Hardenburg et al., 1986). The rate of fresh produce deterioration increases by $2-3$ folds with for every $10^{\circ} \mathrm{C}$ increase in temperature (Kader, 2002).Temperature also determines spore germination and growth of pathogens (Danladi ,2000; Ladaniya, 2008).

The delay in cooling will shorten post-harvest life and reduce quality. Field container should also be placed in the shade or loosely covered with leafy plant materials, straw or an inverted empty container (Kitinoja and Kader, 2002). However, repeated cooling and warming of horticultural products cause deterioration. Extremely high temperatures or exposure of agricultural produce to direct sunlight is equally dangerous. The higher the temperature, the shorter the storage life of agricultural produce and the greater post-harvest loss (Kiaya, 2014).

\subsection{Low temperature}

Horticultural crops differ in their sensitivity to low temperature. Generally crops of temperate origin and some tropical and sub-tropical crops can tolerate temperatures just above their freezing point (Yahia, 2004). However, most crops of tropical and sub-tropical origin are sensitive to very low temperatures. Low temperature injury occurs at different temperatures (from 0 to $18^{\circ} \mathrm{C}$ ) depending on the type of crop, maturity stage and storage duration. Various physiological and biochemical alterations as well as cellular disfunction occur due to chilling injury. Some of these alterations include increase in respiration rate and in ethylene production, increase in activation energy, reduction in photosynthetic activity, alteration in energy production, slowing in protoplasmic streaming, and increase in tissue permeability, enzyme inactivation, membrane disfunction and alteration of cellular structure (Wang, 1993).

The degree of chilling sensitivity and the lowest safe storage temperature is crop specific. Those crops that are chilling sensitive should be held at temperature generally above $50{ }^{\circ} \mathrm{F}\left(10{ }^{\circ} \mathrm{C}\right)$. Horticultural commodity exposed below this threshold will give rise to a physiological disorder known as chilling injury (Sargent et al., 2007).

Some commodities (chiefly those native to the tropics and subtropics) respond unfavorably to expose at low temperatures which are well above their freezing points, but below a critical temperature termed their chilling threshold temperature or lowest safe temperature. Chilling injury is manifested in a variety of symptoms including surface and internal discoloration, pitting, water soaking, failure to ripen, uneven ripening, development of off flavors and heightened susceptibility to pathogen attack (Kader, 2013). Exposure to prolonged periods of chilling stress will lead to irreversible symptoms such as surface lesions and pitting, internal discoloration, water-soaking of the tissue, off flavour, failure to ripen and decay. Chilling injury is reported to be due to a change in the physical state of biological membranes (Lyons, 1973; Toivonen and Hodges, 2011).

The right temperatures for every agricultural produce must be known to prevent chilling injuries (crucial for tropical crops) that adversely affect their quality in terms of discoloration, uneven ripening and failure to ripen as well as exposing them to pathogen attack. Generally, the shelf life of horticultural produce is lengthened when they are kept at fairly lower temperatures (Kader\& Rolle , 2004). The shelf lives of most of the perishable agricultural produce are increased when they are kept in temperatures of approximately $0^{\circ} \mathrm{C}$ (Kader \& Rolle, 2004). Extremely low temperature of agricultural produce, especially tropical fruits (below $10^{\circ} \mathrm{C}$ ) is dangerous as it reduces their shelf life (Arah et al., 2016).

Chilling injury symptoms are characterized by development of sunken lesion on the skin, increased susceptibility to decay, increased shrivels and incomplete ripening as shown by poor flavor, texture, aroma and color. Those crops not sensitive to chilling injury may be stored at temperature as low as $32{ }^{\circ} \mathrm{F}\left(0^{\circ} \mathrm{C}\right)$. The severity of chilling symptoms is also dependent on the length of exposure to low temperature. Short exposure times will result in less injury than longer exposure to chilling temperature (Sargent et al., 2007).

Chilling injury susceptibility is a significant issue for many crops derived from subtropical and tropical growing regions. Generally fruits, fruit vegetables (fruits which are consumed as vegetables), vegetables and root and tuber crops are chilling sensitive (Toivonen, 2011). Chilling injury which is cause by low but not freezing temperature is mainly observed with tropical and subtropical fruits and vegetables. However, the symptoms cause by chilling injury may not be evident while the fruits and vegetables are held at chilling temperature but may become visible only when the fruits and vegetables are transferred to room temperature $\left(37^{\circ} \mathrm{C}\right)$ (Danladi, 2000).

Perishable commodities are generally high in water content and possess large, highly vacuolate cells. The freezing point of their tissues is relatively high (ranging from $-3{ }^{\circ} \mathrm{C}$ to $-0.5{ }^{\circ} \mathrm{C}$ ), and disruption caused by 
freezing generally results in immediate collapse of their tissues and a total loss of cellular integrity. Freezing occurs in cold storage systems either due to inadequate refrigerator design or to thermostat failure (Kader, 2002).

\subsection{Improper Relative humidity}

Relative humidity $(\mathrm{RH})$ is the moisture content (as water vapor) of the atmosphere, expressed as a percentage of the amount of moisture that can be retained by the atmosphere (moisture holding capacity) at a given temperature and pressure without condensation. The moisture holding capacity of air increases with temperature. Water loss is directly proportional to the vapor pressure difference (VPD) between the commodity and its environment. VPD is inversely related to RH of the air surrounding the commodity (Kader, 2013).

RH can influence water loss, decay development, the incidence and severity of some physiological disorders and uniformity of fruit ripening. Condensation of moisture on the commodity (sweating) over long periods of time is probably more important in enhancing decay than is the RH of ambient air (Kader, 2013). Relative humidity (RH) effects on vegetable inherent quality are interrelated with the storage temperature. High temperature and relative humidity favour growth of microorganisms which cause extensive damage to the produce. Humid tropical climate conditions favours decay of bruised yam tubers and also encourages the proliferation of harmful organisms. Excess moisture promotes the growth of fungi and other spoilage microorganisms. This increases susceptibility of improved varieties of produce to moulds and insect pests (Akinbode, 1983; Perez et al., 2003; Nunes, 2008).

\subsubsection{Ethylene Cause}

Ethylene $\left(\mathrm{C}_{2} \mathrm{H}_{4}\right)$ is the simplest organic compound known to affect the physiological processes in plants. Ethylene is naturally produced by all plant tissue, triggers several effects at very low concentrations (ppm or less) and regulates many aspects of development and senescence. Generally, climacteric crops produce more ethylene compared to non-climacteric crops. However, the exposure of all horticultural crops to ethylene accelerates their senescence (Yahia, 2004).

Ethylene is commercially used in postharvest handling to accelerate ripening and to improve the colour of several fruits such as bananas, tomatoes and oranges. Ethylene causes several problems such as tissue softening, abscission and opening of flowers. Exposure of carrots to ethylene was highly correlated with the formation of phenolic compounds such as isocoumarin that contribute to the development of bitter flavour during storage (Lafuente et al., 1989).

According to Abeles (1992) the promotion of senescence in harvested horticultural crops by ethylene (1 ppm or higher) results in acceleration of deterioration and reduced post-harvest life. Ethylene accelerates chlorophyll degradation and induces yellowing of green tissues, thus reducing the quality of leafy, floral and immature fruit-vegetables and foliage ornamentals. Ethylene induces abscission of leaves and flowers, softening of fruits and several physiological disorders.

Ethylene may increase decay development of some fruits by accelerating their senescence and softening and by inhibiting the formation of anti-fungal compounds in the host tissue. In some cases, ethylene may stimulate the growth of fungi, such as Botrytis cineria on strawberries and Penicillium italicum on oranges. The incidence and severity of ethylene-induced deterioration symptoms is dependent upon temperature, time of exposure and ethylene concentration. Ethylene effects are cumulative throughout the post-harvest life of the commodity (Abeles , 1992).

\subsubsection{Lack of knowledge/Skill}

High postharvest losses can be as a result of ignorance in scientific and technological techniques associated with the conservation of food products. Poorly maintained packing cold stores, with limited space and shortage of qualified trained personnel to conduct timely repairs, also impact negatively on the quality of fresh produce. Surplus produce due to lack of market availability coupled with change in destination of produce, creates prolonged storage thus increasing susceptibility of produce spoilage (Tadesse, 1991; Kitinoja, 2010; Hodges et al., 2011).

Fruit production activity is at infant stage in most parts of the country including in Northwestern Ethiopia and both small scale fruit producers and traders have very limited knowledge and skill on fruit production and postharvest handling practices. In this connection high amount of fruits is expected to be wasted due to several inappropriate production and postharvest handling practices. The human element in postharvest handling of horticultural commodities is extremely important. Most handlers involved directly in harvesting, packaging, transporting and marketing in developing countries have limited knowledge, ineffective and far reaching educational program how to maintain quality (Kader, 2005).

Loading of two or more agricultural produce in one transporting vehicle, usually, no attention is given to commodity compatibility. Due to the lack of knowledge on commodity compatibility, farmers often times transport ethylene sensitive commodities together with ethylene generators (Atanda et al., 2011). For instance, transporting of green leafy vegetables such as lettuce, cucumbers, broccoli, Kales, Spinach, matured green tomatoes and carrots that are ethylene sensitive commodities with high level producing ethylene agricultural produce such as apples, mangoes, pears, bananas, tomatoes and peaches result in great post-harvest losses. (Silva, 
2008) points out that this situation results in rust spotting on lettuce, the yellowing or loss of the green colour of ethylene-sensitive vegetables, development of bitter taste in carrots and sprouting in potatoes.

The educational attainment of the farmer including his attendance in informal training related to postharvest technology is another factor that needs to be considered. Their participation in various seminars, workshops and informal training on farming techniques would enable them to be receptive to the adoption of appropriate technology. Some investigations of the farmers' attitude disclosed that some of them are not aware of proper handling practices since they are more concerned with pre-harvest losses due to flood, drought, insect damage etc. In some view loss of products as the result of God's punishment or God's mercy; others associated loss to chance or bad luck etc. under developed infrastructure (roads, harbor facilities), lack of training and awareness among people involved in the marketing system may cause postharvest loss (Simson and Martha, 2010).

Poor packing design (reduces efficiency and increases the risk of mechanical and biological hazards). Avoid improper packing (lack of ventilation, low material resistance, sharp and wrinkled surfaces, etc.), Over packing (many product layers), inappropriate pile up during packing, Packing products with different degree of maturity and mechanical damages caused by personnel or improper design of mechanical grading machines (Zenebe $e t$ al. ,2015).

\subsubsection{Unavailability of tools and limited facilities}

Some special tools and/or equipment in harvesting and postharvest handling, they most likely will not be able to find them in the domestic market. This is true of harvesting aids; containers; equipment for cleaning, waxing, packing and cooling facilities. Most of the tools are neither manufactured locally nor imported in sufficient quantity to meet demand (Kader, 2005). Use of inappropriate harvesting tools facilitates mechanical injuries which in turn accelerate loss of water and vitamin C (Opara, 2007; Arazuri et al., 2010). Furthermore delays between harvesting and cooling promote water, flavour and nutritional value loss as well as decay (Kader, 2002).

Vegetable loss is most prevalent when there is unavailability of essential tools and equipment coupled with poor maintenance and unavailability of spare parts (Kader, 1983). Inadequate infrastructure and advanced production techniques remain major obstacles contributing to food losses for many developing countries (Parfitt et al., 2010). This can be evidenced by the huge variation in magnitude of postharvest losses observed from farm to retail for developed and developing countries respectively. Losses in USA range between $2-23 \%$ whilst losses exceed $50 \%$ in the less technically advanced countries (Kader, 2002). Lack of packing houses is a major postharvest challenge, with vegetables and fruits being generally packed in the field and some even transported without transit packaging (Reardon et al., 2007). (Mittal, 2007) highlights that at least 30\% of vegetable and fruit produce in different countries are wasted primarily from lack of cold chain facilities.

Limited access exists to facilities such as stores, cold rooms, drying and curing rooms increase post harvest losses of horticultural commodity (Simson and Martha, 2010). Careless handling of the packed produce during loading and unloading, corrugated roads leading to maximum vibration of the vehicles, lack of storage facility, tightly squeezed packages into the vehicles and lack of air circulation facility within vehicles leading to heat buildup inside the vehicles cause deterioration and finally loss of the produce (Kader, 2004).

\subsubsection{Inappropriate packaging}

Packaging is an important factor in reducing losses, as well as extending the shelf life of fresh fruits and vegetables. Therefore, one of the major reasons that fruits and vegetables are lost at post-harvest stages is improper packaging and use of unsuitable packaging material. Poor quality packaging materials cannot adequately protect the fresh produce from damages and can even accelerate spoilage of fresh produces. Unfortunately, low-quality packaging materials are widely used in many parts of the world due to their low cost. Especially, use of poor quality packaging container is more common in developed and developing countries. Even some of delicate fruit and vegetables are packed in poly-sacks that severely damage to the delicate products. According to a study carried out in some countries in Sub-Saharan Africa and South Asia, $46 \%$ of horticultural crops were packed in cloth bundles or large sacks, $31 \%$ of them were packed in open baskets and $8 \%$ had no package at all (Kitinoja \& AlHassan, 2010).

The use of sharp-edged packaging containers often leads to puncturing and bruising of agricultural products (Arah et al., 2016). Poor packaging and storage systems are the cause of post-harvest losses in terms of loss in quantity, weight, and nutritional value of agricultural produce. Crude packaging and improper packing of agricultural produce in tractors results in great losses (Kumar et al, 2006) due to the great amassment of heat in the packaged agricultural produce. Crude packing practices such as packing fresh produce either too tight results in compression and bruising while packing them too loosely can equally result in bruising due to the vibrations from each of the fresh agricultural produce in the container (Sparks, 2013). The packaging material is also a major factor in protecting agricultural produce from post-harvest losses. (Esguerra and Rolle, 2018) poor packaging materials and containers that fail to protect the state and original condition of the agricultural produce exposes them to great losses.

In marketing fresh agricultural produce, good packaging habits must be implemented. This is because it has been noted by agricultural experts and food technologists that at the retail level, the shelf life of a considerable 
number of agricultural products sold in unpacked form is lost (Kiaya, 2014).

\subsubsection{Inadequate storage}

The lack of proper storage facilities in developing countries is seen as the main cause of post-harvest losses. Inadequate storage facilities at the producing or marketing centers, exposes the produce to the natural causes of losses i.e damage by micro-organisms, respiration, transpiration and other biochemical reactions (FAO, 2013).

Poor warehouse and storage facilities that expose agricultural produce to high humidity, poor ventilation, microbial and pathogenic attacks often result in great post-harvest losses (SATNET, 2014). (Kumar et al., 2006) recount the great losses of onions as a result of storage losses from poor storage environment that caused fungi and bacteria attack, rottenness, discolouration and spoilage.

In the selecting of agricultural produce for storage, care must be taken not to mix high quality produce with damage produce from bruises and skin cracks. Also, agricultural products with high moisture content must be well dried before they are stored. Storing agricultural produce with high moisture content increases microbial attack. The storage environment must be protected from all forms of environmental hazards that would be detrimental to the agricultural produce (Atanda et al., 2011).

To mix high quality agricultural produce with damage produce from bruises and skin cracks in the storage increase post harvest loss. Storing agricultural produce with high moisture content increases microbial attack. The storage environment must be protected from all forms of environmental hazards that would be detrimental to the agricultural produce (Atanda et al., 2011).

Poor warehouse and storage facilities that expose agricultural produce to high humidity, poor ventilation, microbial and pathogenic attacks often result in great post-harvest losses (SATNET, 2014). (Kumar et al., 2006) recount the great losses of onions as a result of storage losses from poor storage environment that caused fungi and bacteria attack, rottenness, discolouration and spoilage.

\subsubsection{Inadequate Transportation Facilities}

Transportation and distribution of fruits and vegetables are the important stage of post-harvest loss. The physical and mechanical damage occur during transportation and distribution. Longer shipment and distribution period eventually caused heavy losses (Mustapha and Yahaya, 2006; Hayatu, 2000).

Transportation places a certain period of time between production and consumption, it can be one of the main causes of losses, especially for fresh products. In developed countries, delivery of perishable foods with refrigerated vehicles is a standard practice. Losses in such cases occur when the cooling system in the vehicle is broken down, when an accident occurs or when there is a delay in the loading/unloading areas. In developing countries, the absence of appropriate means of transport, poor roads and inefficient logistics management prevent perishable foods from being properly preserve. In addition, loading and unloading operations are carried out in these countries by unskilled and uneducated workers who generally do not carry products carefully. This causes mechanical damage in agricultural products (Azabağaoğlu, 2018).

In most developing countries, roads are not adequate for proper transport of horticultural crops. Also, transport vehicles and other modes, especially those suited for fresh horticultural perishables, are in short supply. This is true whether for local marketing or export to other countries. The majorities of producers have small holdings and cannot afford their own transport vehicles. In a few cases, marketing organizations and cooperatives have been able to acquire transport vehicles, but they cannot do much about poor road conditions (Kader, 2005).

Poor transportation procedures, practices and means contribute to post-harvest losses. Inappropriate means of transporting agricultural produce such as human labour, donkeys, public transports (Arah et al., 2016) leads to both primary and secondary post-harvest losses.

Transport conditions and transport distance play an important role in influencing the magnitude of post harvest loss. Larger distance, bad modes of transport and outdated use of storage containers lead to post harvest loss. About half of the losses are due to physical injuries and improper handling during storage, and distribution (Cortez et al., 2000). Losses during transportation can be high, particularly in developing countries due to lack of sophisticated means of transportation.

These units are made as large as possible and packed as full as possible in order to save on transport costs. As a result product losses are high and crates are too heavy and too large to be carried by one person (Simson and Martha, 2010).

Transportation delay is reported as costing 20\% of post-harvest losses in Africa (Babatola, 2008). According to SATNET (2014) $20 \%$ of yam tubers in Africa are lost due to delays in transporting agricultural produce from vehicular breakdowns. Also, applying high speed on rough and bad road networks (Sparks, 2013) by vehicular drivers transporting agricultural produce results in post-harvest losses.

Enormous losses can be incurred when there is inadequate transportation to move fresh produce to the food market before it spoils (Caixeta-Filho, 1999). Delicate, sensitive produce is often thoughtlessly, roughly handled during transporting and the damage caused greatly enhances further deterioration from physiological and pathological causes (Yahia, 2008).Use of ordinary open and non-refrigerated trucks, poorly ventilated, on very 
rough and poorly maintained roads (Tadesse, 1991). Likewise, the absence of vent tubes in transporting vehicles to reduce the heat of respiration while transporting fresh agricultural produce is identified as one of the causes of post-harvest losses (Kitinoja and Kader, 2002).

Common in transporting vehicles in developing countries, there is no material covering their tops, exposing the agricultural produce to the harsh rays of the sun and predatory flying birds. The use of dirty, no-ventilation and/or poorly ventilated vehicles (Dudi, 2014) exposes the agricultural produce to pathogenic, biological and microbial attacks. Shortage of chartered planes and cancellation of regularly scheduled flights are major causes of postharvest losses of export crops contributing to rapid deterioration of produce at destination (Tadesse, 1991). 2.3.2.9. Inadequate Marketing Systems

Growers can produce large quantities of good-quality fruits and vegetables but if they do not have a dependable, fast and equitable means of getting such commodities to the consumer, losses will be extensive. This problem exists in many locations within developing countries. It is accentuated by lack of communication between producers and receivers and lack of market information (Kader, 2005).

The horticulture products in Ethiopia are mainly produced by smallholder farms and most of the farmers sell their products on nearby market and a few sell both on farm and in nearby market such that the marketing condition is unsatisfactory and discouraging (Seid., 2013). The reasons for unsatisfactory market condition indicated that higher supply of the produce at a time, middle men exploitation and products sell on farm and on the nearby market.

Similarly scientist reported lack of market to absorb the production, large number of middlemen in the marketing system, absence (weakness) of marketing institutions safeguarding farmers' interest and rights over their marketable produces, lack of coordination among producers to increase their bargaining power and imperfect pricing system of traders as major problems to producers (Faris, 2016). Another finding on major postharvest loss assessment at Jimma zone elaborated presence of highest percentage loss was sold in the open space being exposed to sun (Adugna et al., 2011).

Although horticultural crops are exported to Djibouti and Somalia, they are not as such standardized. The logistics such as handling, packing, loading and unloading, storage, road and transportation are poor. This results in selling the Ethiopian horticultural products to conventional traditional prices (Wiersinga and de Jager, 2009).

The increasing horticulture production can contribute to the commercialization of the rural economy and creates many jobs. However, expanding the scale of horticulture production is often hindered by lack of market access, market information and many biological factors (Abay, 2007). (Bezabih and Hadera, 2007) also argued seasonal production to be inversely related to price. Information on price, product demand, product supply, market place and buyers and sellers should be gathered.

Wholesale markets in most of the developing countries are in desperate need of improvement in terms of facilities and sanitation. These are overcrowded, unsanitary and lack adequate facilities for loading, unloading, ripening, consumer packaging and temporary storage. In several countries, there are plans to build better wholesale marketing facilities but their implementation has been delayed more because of social and political than financial considerations (Kader, 2005).

Zenebe et al. (2015) reported $45.9 \%$ postharvest loss on banana in Ethiopia, of which about $15.7 \%$ was incurred at farm, 22.1\% at whole sale and 8.1\% at retailer levels. On the other hand, Madrid (2011) estimated that post-harvest losses in developed countries are an average of $12 \%$ from production to retail warehouse, and an estimated $20 \%$ at retail stores and food service sites.

The desired level of development in horticulture has not been achieved because of a number of constraints. Due to absence of proper storage and marketing facilities and seasonal surplus, farmers are forced to sell their products at thrown-away prices and at the earliest opportunity after harvest (Wei et al., 2001). This also forces producers to sell their horticultural crops at very low prices for their customers. Furthermore, the lack of ability in business planning, lack of marketing knowledge and the perish ability of their products contribute to their weak influential position in the supply chain (Wei et al., 2001).

Wholesale markets in most of the developing countries are in desperate need of improvement in terms of facilities and sanitation. These are overcrowded, unsanitary and lack of adequate facilities for loading, unloading, ripening, consumer, packaging and temporary storage (Kadar, 1983).

Even though fruit and vegetables are produced in high quantities and with acceptable quality the products also need to reach the consumer in an efficient way, or losses will occur (Kader, 2004). This is the case in many developing countries, often due to bad communication between actors and shortage of market information. Another factor contributing to losses of fresh produce is the poor wholesale markets in many developing countries.

Policy changes (e.g. agricultural diversification, quality standards, price policy may cause postharvest loss of horticultural products. under developed infrastructure (roads, harbor facilities), lack of training and awareness among people involved in the marketing system may cause postharvest loss. These units are made as large as possible and packed as full as possible in order to save on transport costs. As a result product losses are high and 
crates are too heavy and too large to be carried by one person (Simson and Martha, 2010).

\subsubsection{Government Regulations and Legislations}

The degree of governmental controls especially on wholesale and retail prices of fresh fruits and vegetables varies from one country to another. In many cases, price controls are counter-productive. Although intended for consumer protection, such regulations encourage fraud and provide no incentive for producing high-quality produce or for postharvest quality maintenance. On the other hand, regulations covering proper handling procedures and public health aspects (food safety issues) during marketing are, if enforced properly, very important to the consumer (Kader, 2005). Policy changes (e.g. agricultural diversification, quality standards, price policy may cause postharvest loss of horticultural products (Simson and Martha, 2010).

\subsubsection{Poor Maintenance}

In many developing countries, some good facilities that were built a few years ago are currently "out of order" or not functioning properly because of lack of maintenance and unavailability of spare parts. This problem is especially true of public-sector facilities. Any new project should include in its plan adequate funds for maintenance to ensure its success and extended usefulness (Kader, 2005).

\subsubsection{Economy status}

The magnitude and pattern of post-harvest losses (PHLs) therefore vary across countries based on their stage of economic development. In high and middle income countries, significant losses occur in the early stages of the food supply chains and at the consumer level (UN, 2011).

Food losses in the developed countries are generally low in the middle stages of the supply chain. This can be attributed to more-efficient farming systems, better transport, better management, storage, and processing facilities which ensure that a larger proportion of harvested output is delivered to the markets (Hodges et al., 2011). The extensive and effective cold chain systems, prevalent in these countries, also help to prolong the shelf-life of food products.

Income is very important as it affects largely the level of capital investment of farms. The income generated from farm to off-farm sources would determine whether the farmer is financially capable of reducing postharvest losses through investment on better packaging materials or storage facilities. Low investment has been argued as the main chain effect of low income. The lack of adequate capital inhibits farmers from buying recommended containers for transport. Most often, farmers may harvest immature crops mainly fruits and vegetables during times when they need immediate cash for the family and/or when prices are high.

In contrast, food losses in the low-income countries mainly occur in the early and middle stages of the food supply chains with proportionally less amounts wasted at the consumer level. Food losses in these countries are the result of "inadvertent losses" due to the 'poor' state of their supply chains. Premature harvesting, poor storage facilities, lack of infrastructure, lack of processing facilities and inadequate market facilities are the main reasons for high food losses along the entire Food Supply Chain (FSC) (Hodges et al., 2011).

\subsubsection{Social and cultural factors}

Social and cultural factors such as urbanisation, education and population growth and its characteristics can influence the quantity and quality of produce available. Traditional processing and marketing systems can be responsible for high losses (Parfitt et al., 2010). Poor sanitation facilities and in wholesales including overcrowding, and lack of adequate facilities for loading and unloading of produce can indirectly contribute to serious fresh produce losses too. Fresh vegetable losses can also be a direct result of human psychology whereby a fresh commodity is not eaten and is thrown away because the end user did not fancy eating it or for religious taboos (Parfitt et al., 2010).

\subsubsection{Consumers' waste}

Consumption stage lasts from the moment of purchase by consumers of fruit and vegetable to the moment of consumption. Considerable losses for fruit and vegetable occur at consumption stage in the food supply chain. Fresh fruit and vegetables contribute to almost $50 \%$ of food wasted by households. According to a study conducted by FAO (2011), fruit and vegetable correspond to $39 \%$ of total household waste. In another study carried out by WRAP (2008), this ratio reaches up $40 \%$ of the total household waste. The main causes of the consumers' waste are due to over-purchasing, lack of planning, poor home-storage management, etc. Magnitude of consumers' waste depends on both socio-cultural and material factors such as gender, lifestyle, income and home storage facilities (Porat et al., 2018).

Studies indicated that in developing countries major food losses occur due to technical and managerial limitations in harvesting techniques, storage, transportation, and processing activities, lack of proper cooling facilities, infrastructure, packaging and marketing systems. Conversely, postharvest loss relates mainly to consumer behavior, quality standard requirements and strict safety policies for fruit and vegetable in developed countries (FAO, 2011; FAO, 2015).

\subsection{Post harvest loss extent}

Depending on horticultural commodity and season of production losses are estimated at 20 to $40 \%$ in developing 
countries and 10 to $15 \%$ in developed countries (Kader, 2005; Garnett, 2006; Ogunleye and Adefemi, 2007; Madrid, 2011). It is estimated post-harvest losses in developed countries are an average of $12 \%$ from production to retail warehouses and estimated $20 \%$ at retail stores and food service sites (Madrid, 2011). Losses in developing countries run even higher because of poor storage and food-handling technologies (Salami et al., 2010).

Durable and perishable commodities are prone to widespread postharvest diseases that cause huge spoilage to the produce. Greater losses in developing countries is due to non-availability of proper storage and transportation facilities and improper handling methods, resulting in greater levels of injuries or wounds during harvesting and transit (Majumdar and Pathak , 1989); ( Pathak, 1997). It is estimated that about 20-25\% of the harvested fruits and vegetables are decayed by pathogens during postharvest handling even in developed countries. In developing countries, postharvest losses are often more severe due to inadequate storage and transportation facilities (Sharma et al., 2009).

Postharvest losses for fresh commodities (fruits and vegetables) are about $5 \%$ in developed countries and may average 30-50 \% in underdeveloped countries (China., 2007). In developing countries losses are more, due to non-availability of proper handling methods, transportation and storage facilities, which results in greater levels of injuries or wounds during harvesting and transit.

Losses of fresh fruits and vegetables in developed countries are estimated to range from 2 percent for potatoes to 23 percent for strawberries with an overall average of 12 percent losses between production and consumption sites. In contrast, the range of produce losses in developing countries varies widely. Overall, about one third of horticultural crops produced are never consumed by humans. The extent of loss in perishables depends upon type of commodity 5-100 per cent. The post harvest loss in developed countries is much less as compared to developing countries (Kaminski and Christiaensen, 2014).

Post-harvest loss and quality deterioration of horticultural crops are estimated to be $25-40 \%$ (Yohannes, 1989). Kader et al. (2012) reported that about one-third of the food produced is wasted in developed and developing countries which accounts to 1.3 billion tons per year. In medium- and high-income countries, a lot of food is discarded while it is still suitable for human consumption (more than $40 \%$ of the losses occur at the retail and consumer levels) while in developing countries, food losses occur early in the food supply chain at postharvest and processing stages.

According to Salami et al., (2010) about $30-40 \%$ of fruits and vegetables are lost or discarded after leaving the farm gate. Kader (2002) also estimated that postharvest losses in fresh fruits and vegetables are 5 to $35 \%$ in developed countries and 20 to 50\% in developing countries. Fresh fruits and vegetables are wasted throughout the food supply chains from initial agricultural production down to final household consumption.

Production of fruits and vegetables in Sub-Saharan Africa as of 2014 is approximately at 34.22 and 31.95 million tons, respectively (FAOSTAT, 2017). At the same time, postharvest losses of fruits and vegetables in Sub-Saharan Africa range from 30 to $80 \%$ depending on nature of the crop, while globally postharvest losses is estimated at 30\% (Ghosh, Fawcett, Sharma, \& Poinern, 2016; Gustavsson et al., 2011; Kitinoja et al., 2011; Niewiara, 2016; Singh et al., 2014).

Ethiopia's Ministry of Agriculture is striving to minimize post-harvest losses, which is causing up to 20 $40 \%$ losses in sub-Saharan Africa (FAO, 2009). The post-harvest losses of perishable (vegetable and fruits) food crops amounted to be about 30\% (Fekadu and Dandena, 2006) due to the presence of high moisture content (65$95 \%$ ), insect infestation and damage during post-harvest handling techniques (packaging, storage and transportation).

Higher postharvest losses not only reduce the availability of fruits but also result in increase in per unit prices of the produce and thus limit the accessibility by the majority of community segments. Postharvest loss as going beyond the loss of the actual crop to include loss in the environment, resources, labor needed to produce the crop and livelihood of the individual involved in the production process. However, it is important to note that much is being invested to production compared to postharvest handling, though 30 to $50 \%$ of the produce is wasted in few days after harvest (Kughur et al., 2015). In one-third of the food produced worldwide for human consumption is lost after harvest (Gastavsson et al., 2011).

The estimated post-harvest losses of fruits and vegetables range from $20 \%$ to $40 \%$ (Wiersinga and de Jager, 2009). Increased returns to growers might come from proper management after harvest (Wiersinga and de Jager, 2009). Post-harvest losses may vary greatly among commodities, production areas and seasons, handling and management practices. Nearly $20 \%$ of losses of fresh fruits and vegetables are due to product deterioration. This may include the excess of perishable products that are discarded and the food that is wasted, not consumed by the purchaser) (Kader, 2005; Victor, 2014). The extent of loss in perishables depends upon type of commodity (Hodges et al., 2011). Along with roots and tubers, fruit and vegetable have the highest wastage rates of any food product; almost half of the fruit and vegetable produced are wasted (Kitinoja and Kader, 2015).

Post-harvest loss ranges from about $21 \%$ for cereals up to $66 \%$ for fruits and vegetables in Sub-SaharaAfrican food value chains. Studies conducted in Ethiopia on seven fruit and vegetable crops (tomato, cabbage, 
onion, potato, mango, banana and avocado) revealed that the total average post-harvest losses range from 14 to $60 \%$. Highest losses observed on cabbage were $58.9 \%$ and lowest loss $(14.1 \%)$ recorded on onion crop (Gebresenbet et al., 2016). The horticultural produce losses are as high as 50 percent due to inefficient postharvest procedures (Oyeniran, 1988).

According to CSA (2012/13) during the main production season about 192,555.39 and 4,793,360.64 hectares of land were under production of vegetables and fruits in Ethiopia, respectively. The rough estimation of yearly global quantitative food losses and waste reached at $40-50 \%$ for fruits, vegetables and root crops grown in Ethiopia (FAO, 2012).

According to CSA (2012/13), bananas, mangoes, papayas and oranges took up $63 \%, 15 \%, 8 \%$ and $8 \%$ of the fruit production in the country, respectively. More than 479,337 tons of fruits were produced in the country during the production year of (2012/13). It is crucial for the harvested produce to be taken through post-harvest management or technology as soon as the produce is harvested (Dudi, 2014). This is because the rate of the perishability of fresh horticultural produce in terms of post-harvest losses is pegged between 30 percent to 50 percent in fruits and vegetables (Atanda, 2011). (Kumar et al., 2006) concur that agricultural products are biologically active and biochemical processes such as transpiration, respiration, ripening and others that speeds up the depreciation of their quality starts operation immediately after harvesting.

Production losses of fruits and vegetable in developing countries are hard to judge, but some authorities put losses of sweet potatoes, plantain, tomatoes, bananas and citrus fruit sometimes as high as 50 percent, or half of what is grown (Camargo and Perdas ,2002) and (Oyeniran ,1988). Reduction in this wastage, particularly if it can economically be avoided, would be of great significance to growers and consumers alike (FAO, 2012).

Food losses after harvest until the food reach the consumer are significant (FAO, 2014). Post-harvest losses in developing countries can range from 15 percent up to 50 percent. Horticultural crops, such as fruits, are perishable products and therefore sensitive which leads to greater losses than for non-perishable crops (Parfitt $e t$ al., 2010). The extent of losses and wastage that occur throughout the food supply chains is very high. Not only losses are clearly a waste of food but also they represent a similar waste of human effort, farm inputs, livelihoods, investments and scarce recourses such as water (WRI, 1998).

The magnitude of losses and waste are still lacking, particularly in developing countries. Generally, FAO (2012) roughly estimated that yearly global quantitative food losses and waste reached at 40-50\% for fruits, vegetables and root crops. Olayemi et al. (2012) also estimated that as much as $25 \%$ and $40 \%$ fruits and vegetables, respectively, are lost after harvest and concluded that farmers experienced serious postharvest losses particularly due to poor postharvest handling.

Vegetables are very diverse in their morphology and this is an important determinant of postharvest quantitative losses. Leafy vegetables are more perishable than roots and tubers and also easily susceptible to wilting, mechanical injury and decay (Kitinoja, 2010).

\section{CONCLUSION}

Agriculture is the foundation of Ethiopian economy. Post-harvest loss of fruit and vegetable is a matter of great economic concern in agriculture. Quantitative post-harvest losses and quality deterioration of horticultural crops are mostly caused by biological, microbiological, mechanical injury, physical damage; physiological and environmental conditions and inappropriate post-harvest handling. A problem in the supply chain for fruits and vegetables in Ethiopia is that the knowledge about post-harvest handling is limited and the post-harvest losses are high. Losses occur in all post-harvest activities such as handling, storage, processing, packaging, transportation and marketing. Therefore; to increase food availability, it is not enough to increase the productivity in agriculture there is also a need to know major cause of post harvest loss of horticultural commodity and lower the higher extent of post harvest losses.

Currently there are limited literatures to review on the cause and extent of postharvest losses of fresh fruits and vegetables in Ethiopia due to lack of research works in the sector. Although, it is possible to estimate such losses of perishables horticultural commodity based on the annual production data of central statistics agency (CSA) and food and agricultural organization of the country (FAO). It is too early to reach a conclusive recommendation since limited study were conducted in the cause and extent of post harvest loss of horticultural crops. Hence, in addition to applying appropriate post harvest handling, further studies must be done to tackle the cause of post harvest loss of horticultural crops and minimized the extent of post harvest losses.

\section{REFERENCES}

Abay, A., 2007. Vegetable market chain analysis in Amhara National Regional State: the case of Fogera Woreda, South Gondar Zone. M.Sc. Thesis. Haramaya University.

Abeles, F.B., Morgan, P.W., Saltveit ME (1992). Ethylene in Plant Biology, vol. 15, 2nd ed. Academic Press, San Diego, California.

Adeoye, I.B., O.M.O. Odeleye, S.O. Babalola and S.O. Afolayan. 2009. Economic Analysis of Tomato Losses in 
Ibadan Metropolis, Oyo State, Nigeria. African Journal of Basic \& Applied Sciences, 1 (5-6): 87-92. ISSN 2079- 2034

Adugna D, Gerba D, Diriba B, Kassaye T (2011) Identification of major causes of postharvest losses among selected fruits in jimma zone for proffering veritable solutions. International Journal of Current Research, 3(11). (Adugna et al.,2011)

Affognon, H., Mutungi, C., Sanginga, P., \& Borgemeister, C. (2015). Unpacking postharvest losses in subSaharan Africa: A meta-analysis. World Development, 66, 49-68. http://dx.doi.org/10.1016/j.worlddev.2014.08.002.

Agrios, G.N. (2005). Plant Pathology. $5^{\text {th }}$ eds. Elsevier Inc. Academic Press, USA. 553p.

Akinbode, I.A. (1983). A comparative analysis of the adaptation of post-harvest loss prevention practices by farmers and traders in Oyo state of Nigeria. Agricultural Wastes, 5, 179-188.

Alazar, A.( 2007). Horticultural Marketing in Ethiopia. M.Sc. Thesis. Haramaya University, Haramaya.

Antunes, D., Miguel, G. \& Neves, A. (2007). Sustainable Post-harvest Handling of Horticultural Products. WSEAS Transactions on Environment and Development, vol. 3, Issue 6

Arah, I. K., Ahorbo, G. K., Anku, E. K., Kumah, E. K. and Amaglo, H. (2016). Postharvest Handling Practices and Treatment Methods for Tomato Handlers in Developing Countries: A Mini Review. Advances in Agriculture, vol. 2016, pp. 1- 8, Hindawi Publishing Corporation.

Arazuri, S., Arana, I. \& Jaren, C. (2010). Evaluation of mechanical tomato harvesting using wireless sensors. Sensors, 10(12), 11126-11143.

Atanda, S. A., Pessu, P. O., Agoda, S., Isong, I. U. and Ikotun, I. (2011). The Concepts and Problems of PostHarvest Food Losses in Perishable Crops. African Journal of Food Science, vol. 5(11), pp. 603-613.

Aulakh, J., and Regmi, A. (2013). Post-harvest food losses estimation-development of consistent methodology. Selected Poster Prepared for Presentation at the Agricultural \& Applied Economics Association's 2013 AAEA \& CAES Joint Annual Meeting, Washington DC.

Azabağaoğlu, M.Ö. (2018). Investigating fresh fruit and vegetables losses at contemporary food retailers. Sosyal Bilimler Araştırma Dergisi, 7(4), 55-62.

Babatola, L. A., Ojo, D. O. and Lawal, O. I. (2008). Effects of Storage Condition on Tomato (Lycopersiconescullentum Mill.) Quality and Shelf Life. Journal of Biological Sciences (2): 490-493.

Babita, B., and Kiranmayi, P. (2010). Effect of storage conditions on postharvest quality of tomato (Lycopersicon esculentum). Reasearch Journal of Agricultural sciences, 1(4), 409-411.

Barbosa-Canovas, G.V., Fernandez-Molina, J.J., Alzamora, S.M., Tapia, M.S., Lopez-Malo, A. and Chanes, J. (2003). Handling and preservation of fruits and vegetables by combined methods for rural areas: Technical Manual. FAO Agricultural Services Bulletin, 149. Food and Agriculture Organisation of the United Nations, Rome.

Bartz, J.A. and Brecht, J.K. (2002). Postharvest physiology and pathology of vegetables, $2^{\text {nd }}$ ed. Marcel Dekker, New York.

Bekele, W., (1989). Horticulture marketing systems in Ethiopia. First international symposium on horticultural economics in developing countries. Acta Hortic. 1, 21-31.

Bezabih, E. and Hadera, G., (2007). Constraints and problems of horticulture production and marketing in Eastern Ethiopia. Dry land Coordination Report, G46, Osolo, p. 91.

Bollen, A.F. (2006). Technological innovations in sensors for assessment of postharvest mechanical handling systems. International Journal of Postharvest Technology and Innovation, 1, 16-31.

Buyukbay, E. O., Uzunoz, M. and Sibel Gulse and Bal, H.(2010). Postharvest Losses in Tomato and Fresh Bean Production in Tokat Province of Turkey. Scientific Research and Essays.,6 (7): 1656 - 1666.

Buyukbay, E.O, Uzunoz, M., Bal, H. (2011). Post-harvest losses in tomato and fresh bean production in Tokat province of Turkey. Sci. Res. Essays 6(7):1656-1666.

Buzby, J. C., Farah-Wells, H., and Hyman, J. (2014). The estimated amount, value, and calories of postharvest food losses at the retail and consumer levels in the United States. USDAERS Economic Information Bulletin 121.

Buzby, J.C. and Hyman, J. (2012). Total and per capita value of food loss in the United States. Food Policy, 37:561-570.

Caixeta-Filho, J.V. (1999). Losses in transportation of fruits and Vegetables: A Brazilian case study. International Journal of Logistics: Research and Applications, 2, 325-341.

China, P.R., (2007). Management of Postharvest Diseases in Stone and Pome Fruit Crops General Concepts in Integrated Pest and Disease Management, 131-147.

Cortez, L., Honorio, S.L. and Mortetti, C.L. (2002). Resfriamento de Frutas e Hortalicas. Embrapa Informacao Tecnologica, Brasilia, DF, Brasil.

CSA (2012). Ethiopia Demographic and Health Survey. Central Statistical Agency: Addis Ababa, Ethiopia.

Danladi, D.K. (2000). Nigeria agriculture: The efficiency factor announce this article to your friends. p. 1-3. 
Devkota, A.R., Dhakal, D.D., Gautam, D.M., and Dutta, J.P. (2014). Assessment of fruit and vegetable losses at major wholesale markets in Nepal. Int. J. Appl. Sci. Biotechnol. 2(4):559-562.

Dorais, M.P., Papadopoulos, A.P. and Gosslin, A. (2001). Greenhouse tomato fruit quality. Journal of Horticulture Review, 5, 239-319.

Dudi, J. A. (2014). Assessment of Post-harvest Grain Management Operations and their Effects on Food Security of Smallholder Households in Kisumu County, Kenya. M. A. Thesis, Kenya: University of Nairobi

Elias, S. K., Shaw, M.W. and Dewey, F.M. (2010). Persistent symptomless, systemic and seed-borne infection of lettuce by Botrytis cinerea. European Journal of Plant Pathology 126(1): 61-71.

Esguerra, E.B. and Rolle, R. (2018). Post-harvest Management of Mango for Quality and Safety Assurance. Guidance for Horticultural Supply Chain Stakeholders. Rome: Food and Agriculture Organization of the United Nations.

Etebu, E, Nwauzoma, A.B and Bawo, D.S. (2013). Postharvest spoilage of tomato (Lycopersicon esculentum Mill.) and control strategies in Nigeria. J Biol Agric Healthc.;3(10):51-61.

Faris, A. (2016) Review on Avocado Value Chain in Ethiopia. Industrial Engineering Letters, 6(3):33-40.

FAO (1980), Assessment and Collection of Data on Post-harvest Good Grain Losses, FAO Economic and Social Development Paper 13. Rome

FAO (2014). IFAD (2012) The State of Food Insecurity in the World 2012: Economic growth is necessary but not sufficient to accelerate reduction of hunger and malnutrition. FAO, Rome, Italy.

FAO (1989). Prevention of post-harvest food losses fruits, vegetables and root crops a training manual. Food and Agriculture Organization of the United Nations, Rome. ISBN, 92-5-102766-8.

FAO (2009). Declaration of the world summit on food security. World Summit on Food Security, 16-18 November, Rome;

FAO (2011).Global food losses and food waste extent, causes and prevention.Available at http://www.fao.org/docrep/014/mb060e/mb060e.pdf.

FAO ( 2012). Role of agro-industry in reducing food losses in the middle East and North Africa region;

FAO (2013).Food Losses and Waste in Turkey, Country Report, 48 s. Available at: http://www.fao.org/3/aau824e.pdf

FAO (2015). Global Initiative on Food Loss and Waste Reduction. Available at: http://www.fao.org/3/ai4068e.pdf.

FAO (2016). The state of food and agriculture: Climate change, agriculture and food security. Food and Agriculture Organization of the United Nations. Retrieved 23 October 2016, from www.fao.org/publications.

FAOSTAT (2017). Food and Agriculture Organization of the United Nations. Retrieved February 21, 2017, from http:// www.fao.org/faostat/en/\#data/QC

FAOSTAT (2017). Food and Agriculture Organization of the United Nations. Retrieved February 21, 2017, from http:// www.fao.org/faostat/en/\#data/QC

Fantahun, A. and Williamson, S., (2001). Ethiopian farmers test alternatives to pesticides. Pestic. News 52, 8-9.

Fekadu M. and Dandena G.(2006). Review of the status of vegetable crops production and marketing in Ethiopia. Uganda J Agric Sci.;12(2):26-30.

Flores, G.A. and Rivas, D. (1975). Studies on the ripening and frozen storage of sapodilla Achras sapota L. Estudios de maduracion y almacenamiento refrigerado de nispero Achras sapota L. Fitotecnia Latinoamericana 11, 43-51.

Garnett, T. (2006). Fruit and vegetables and UK greenhouse gas emissions: exploring the relationship. UK: Food and Climate Research Network, University of Surrey. FCRN working paper 06-01 Rev. A: 1-134.

Gebresenbet, G., Aadom, S. and Metapo, A.M. (2016). Supply chain management approach to rduce postharvest losses of fruits and vegatables, the case of Ethiopia. CIGR-AgEng 2016 Conference, Aarhus, Denmark.

Getachew, D. (2004). Prevention of post-harvest food losses fruits, vegetables and root crops a training manual. Agriculture and Consumer Protection.

Ghosh, P. R., Fawcett, D., Sharma, S. B., and Poinern, G. E. J. (2016). Progress towards sustainable utilisation and management of food wastes in the global economy. International Journal of Food Science.

Gorny, J.R., ed. (2001). Food safety guidelines for the fresh-cut produce industry. Fourth edition. Alexandria, VA: International Fresh-cut Produce Association. 218 pp.

Gross, R., Schoeneberger, H., Pfeifer, H. and Joachim, A.H. (2000). The Four Dimensions of Food and Nutrition Security: Definitions and Concepts. Available at: http://www.foodsec.org/DL/course/shortcourseFA/en/pdf/P-01 RG Concept.pdf

Gustavsson, J., Cederberg, C., Sonesson, U., Van Otterdijk, R. and Meybeck, A. (2011). Global food losses and food waste. Rome: Food and Agriculture Organization of the United Nations.

Hardenburg, R.E., Watada, A.T. and Wang, C.Y. (1986). The Commercial Storage of Fruits, Vegetables and 
Nursery Stocks. Agriculture Handbook No 66. US Dept. of Agriculture. Washington DC.

Hayatu, M. (2000). Post-Harvest physiological studies of some selected members of family Solanaceae.

Helvetas. (2014). Consequences of post-harvest losses to vegetable farmers in Tanzania: a case of Singida region. HELVETAS Swiss Intercooperation Survey Report. 2014; p. 32.

Hodges, R.J., Buzby, J.C. and Bennett, B. (2011). Foresight project on global food and farming futures: Postharvest losses and waste in developed and less developed countries: opportunities to improve resource use. J. Agric. Sci. 149:37-45.

Humble, S. and Reneby, A. (2014). Post-harvest losses in fruit supply chains - A case study of mango and avocado in Ethiopia. Karin Hakelius, Swedish University of Agricultural Sciences, Department of Economics. Available at: http://stud.epsilon.slu.se/7521/1/Humble et al 141205.pdf

Idah, P.A., Ajisegiri, E.S.A. and Yisa, M.O.( 2007). Fruits and vegetables handling and transportation in Nigeria. Aust. J. Technol. 10, 175- 183.

ILRI, (2011). Fruits - A synthesis of IPMS value-chain development experiences. ILRI, Nairobi.

James, A. and Zikankuba, V. (2017). Post-harvest Management of Fruits and Vegetables: A Potential for Reducing Poverty, Hidden Hunger and Malnutrition in Sub-Sahara Africa. Cogent Food and Agriculture, vol. 3: 1312052

Jayne, T.S, Mather, D. and Mghenyi, E.(2010). Principal Challenges Confronting Smallholder Agriculture in Sub-Saharan Africa. World Dev. 38(10):1384-1398.

Kader, A.A. (1983). Postharvest quality maintenance of fruits and vegetables in developing countries. p.455-570. In: M. Lieberman (ed.), Postharvest Physiology and Crop Preservation. Plenum Publ. Corp., New York, NY.

Kader, A.A. (1995). Maturity, ripening, and quality relationships of fruit-vegetables. Strategies for Market Oriented Greenhouse Production 434, 249-256.

Kader, A.A. (2002), Postharvest technology of horticultural crops. 3rd ed. Univ. Calif. Agr. Nat. Resources, Oakland, Publ. 3311p.

Kader, A. A. 2004. Increasing food Availability by reducing postharvest losses of fresh produce. The V International Postharvest Symposium 682 (pp. 2169-2176).

Kader, A.A. (2005), Increasing Food Availability by Reducing Postharvest Losses of Fresh Produce. Pp. 21692176. Proc. 5th Int. Postharvest Symp. Eds. F. Mencarelli and P. Tonutti Acta Hort. 682, ISHS 2005. USA

Kader, A. A. (2009). Handling of horticultural perishables in developing vs. developed countries. Paper presented at the VI International Postharvest Symposium 877, Antalya.

Kader, A.A. (2013). Postharvest technology of horticultural crops- An overwiew from farm to fork. Ethiopian Journal of Science and Technology, 1, 1-8.

Kader, A.A. and Rolle, R.S. (2004). The role of postharvest management in assuring quality and safety of horticultural produce. Food and Agriculture Organization of the United Nations, Rome. FAO Agricultural Services Bulletin, 152. Pp. 1-6.

Kaminski, J. and Christiaensen, L. (2014). Post-harvest loss in Sub-Saharan Africa- What Do Farmers Say? Policy Research Working Paper 6831, World Bank

Kasso, M., and Bekele, A. (2016). Post-harvest loss and quality deterioration of horticultural crops in dire dawa region, ethiopia. Journal of the Saudi Society of Agricultural Sciences.

Kiaya, V. (2014). Post-Harvest Losses and Strategies to Reduce Them. Technical Paper. Scientific and Technical Department. France: ACF International

Kitinoja, L. (2010). Identification of appropriate postharvest technologies for improving market access and incomes for small horticultural farmers in Sub-Saharan Africa and South Asia. WFLO Grant Final Report. Grant number 52198.

Kitinoja, L. and AlHassan, H.Y. (2012), Identification of Appropriate Postharvest Technologies for Small Scale Horticultural Farmers and Marketers in Sub-Saharan Africa and South Asia - Part 1. Pp. 31-40. In: M.I. Cantwell and D.P.F. Almeida (Eds.). Postharvest Losses and Quality Assessments. Proc. XXVIIIth IHC IS on Postharvest Technology in the Global Market Acta Hort. 934, ISHS.

Kitinoja, L.and Kader, A.A. (2002). Small-Scale Postharvest Handling Practices: A Manual for Horticultural Crops, fourth ed. Postharvest Technology Research and Information Center. Davis: University of California.

Kitinoja, L. and Kader, A.A. (2015). Measuring postharvest losses of fresh fruits and vegetables in developing countries. Postharvest education foundation paper 15-02;

Kitinoja, L., Saran, S., Roy, S. K., and Kader, A. A. (2011). Postharvest technology for developing countries: challenges and opportunities in research, outreach and advocacy. Journal of the Science of Food and Agriculture, 91, 597-603. http://dx.doi.org/10.1002/jsfa.4295

Kughur, P.G, Iornenge, G.M. and Ityonongu, B.E. (2015). Effects of postharvest losses on selected fruits and vegetables among small-scale farmers in Gboko local government area of Benue State, Nigeria. Int. J. Innov. Sci. Res. 19(1):201-208.

Kumar, D. K., Basavaraja, H. and Mahajanshetti, S. B. (2006). An Economic Analysis of Post-Harvest Losses in 
Vegetables in Karnataka. Indian Journal of Agricultural Economics, vol. 61, no. 1, pp. 134-146

Ladaniya, M.S. (2008). Citrus Fruit: biology, technology and evaluation. Pp. 67-79 Academic Press, USA.

Lafuente, M.T., Cantwell, M., Yang, S.F. and Rubatzky, U. 1989. Isocoumarin content of carrots as influenced by eyhylene concentration, storage temperature and stress conditions. Acta Horticulturae 258, 523-534.

Lundqvist J, D., Fraiture, C. and Molden, D. (2008). Saving water: from field to fork-curbing losses and wastage in the food chain. In SIWI Policy Brief. Stockholm, Sweden: SIWI, pp.1-36.

Madrid, M. (2011). Reducing postharvest losses and improving fruit quality worldwide: the one-billion-dollar $\begin{array}{llll}\text { untapped business } & \text { opportunity. } & \text { UWWW }\end{array}$ http://www.fruitprofits.com/ing/articulo.asp?reg=26. Accessed 01/Nov/2011.

Majumdar, V.L. and Pathak, V.N.(1989). Changes in nutritional value of guava fruits infected by major postharvest pathogens. Plant Food for Human Nutr., 39: 311-315).

Miedes, E., Lorences, E.P. (2004). Apple ( Malus domestica) and tomato ( Lycopersicum esculentum ) fruits cellwall hemicelluloses and xyloglucan degradation during Penicillium expansum infection. J Agric Food Chem 52(26):7957-7963

Milaku, J.(2005). Patterns and determinants of fruit and vegetable emand in developing countries: a multicountry comparison (Ethiopia). Fruit and Vegetables for Health. Report of a Joint FAO/WHO Workshop, 1-3 September 2004, Kobe.

Miller, A.R. (2003). Harvest and handling injury: physiology, biochemistry, and detection. In: Bartz JA, Brecht JK (eds) Postharvest physiology and pathology of vegetables, 2nd edn. Marcel Dekker, Inc, New York, pp 177-208. ISBN 0-8247-0687-0

Mittal, S. (2007). Strengthening backward and forward linkages in horticulture: Some successful initiatives. Agricultural Economics Research Review, 20, 457-469.

MOARD (2005). Vegetables and Fruits Production and Marketing Plan (Amharic Version), Ministry of Agriculture and Rural Development, Addis Ababa, Ethiopia..

Moss, M.O. (2002). Mycotoxin review. 1. Aspergillus and Penicillium. Mycologist, 16: 116-119.

Moy, G.(2005). Food safety aspects in fruit and vegetables. Fruit and Vegetables for Health (FAO/WHO). Report of a Joint FAO/WHO Workshop, 1-3 September 2004, Kobe.

Munhuweyi, K.(2012). Post-harvest Looses and Changes in Quality of Vegetables from Retail to Consumer: A Case Study of Tomato, Cabbage and Carrot. Master of Science, Faculty of Agricsciences, South Africa: Stellenbosch University

Mustapha, Y. and Yahaya, S.M. (2006). Isolation and Identification of Post-harvest fungi of Tomato ( $L$. esculentum) and Pepper (Capsicum annum) sample from selected Irrigated sites in Kano. Biological and Environmental Science Journal for the Tropics 3: 139-141.

Negi, P.S. and Handa, A.K. (2008). Structural deterioration of the produce: the breakdown of cell wall components. In: Paliyath G, Murr DP, Handa AK, Lurie S (eds) Postharvest biology and technology of fruits, vegetables, and fl owers, vol 978-0-8138-0408-8/2008, 1st edn. Wiley- Blackwell Publishing, Ames. ISBN 978-0-8138-0408-8/2008.

Niewiara, M. (2016). Postharvest loss: Global collaboration needed to solve a global problem. $i$-ACES, 2, $29-36$.

Nunes, M.C.N. (2008). Colour atlas of postharvest quality fruits and vegetables. Pp. 240-243. Blackwell Publishing.

Ogunleye, R.F. and Adefemi, S.O. (2007). Evaluation of the dust and methanol extracts of Garcinia kolae for the control of Callosobruchus maculatus (F.) and Sitophilus zeamais (Mots). J. Zhejiang Univ. Sci. B. 8(12): 912-916.

Olayemi, F.F, Adegbola, J.A., Bamishaiye, E.I. and Daura, A.M. (2010). Assessment of postharvest challenges of small scale farm holders of tomatoes, bell and hot pepper in some local government areas of Kano State, Nigeria. Bayero J Pure Appl Sci.;3(2):39-42.

Olayemi, F.F., Adegbola, J.A., Bamishaiye E.I. and Aawagu, E.F. (2012). Assessment of postharvest losses of some selected crops in eight local government areas of rivers state, Nigeria. Asian journal of rural development, 2(1): 13-23.

Opadokun, J.S. (1987). Reduction of post-harvest losses in fruits and vegetables. Joint National Crop Protection Workshop, IAR, Zaria, p. 3-26.

Opara, U.L. (2007). Bruise and susceptibilities of „Galae apples as affected by orchard management practices and harvest date. Postharvest Biology and Technology, 43, 47-54.

Oyeniran, J.O. (1988). Report of the Nationally Coordinated Research Project on Fruits and Vegetables in Nigeria. Proc. Nat. Workshop on Improved Packaging and Storage Systems for Fruits and Vegetables in Nigeria. Ilorin, Nigeria.

Özcan, M. (2010). Bahçe Ürünlerinde Muhafaza ve Pazarlama Ders Notları. Ondokuz Mayıs Üniversitesi Ziraat Fakültesi Ders Notlar1.

Özdemir, A. E., Dündar Ö., Ertürk E.and Dilbaz R. (2003). Bazı Yörelerimizde Yetiştirilen Starking Delicious 
elmalarında Derim Öncesi ve Derim Sırasında Görülen Kayıpların Belirlenmesi .IV Ulusal Bahçe Bitkileri Kongresi 08-12 Eylül Antalya s. 166-168.

Parfitt, J., Bathel, M. and Macnaugton, S. (2010). Food waste within food supply chains: quantification and potential for change to 2050. The Royal Society, 365, 3065-3081.

Pathak, V.N. (1997). Postharvest fruit pathology: present status and future possibilities. Indian Phytopath., 50: 161-185.).

Perez, K., Mercado, J. and Soto-Valdez, H. (2003). Effect of storage temperature on the shelf life of Hass avocado (Persea Americana). Food Science and Technology International 10, 73-77.

Prusky, D. (2011). Reduction of the incidence of postharvest quality losses, and future prospects. Food Security, 3, 463-474.

Porat, R., Lichter, A., Terry, L.A., Harker, R. and Buzby, J. (2018). Postharvest losses of fruit and vegetables during retail and in consumers' homes: Quantifications, causes, and means of prevention. Postharvest biology and technology.

Reardon, T., Timer, C.P. and Berdegue, J.A. (2007). Supermarket expansion in Latin America and Asia, implications for food marketing systems new directions in global food markets. Chapter 4. Washington, DC: Economic Research Service/USDA.

Rehman, M., Inayatullah, J. and Khan, N. (2007). Post-harvest losses in tomato crop: A case of Peshawar valley. Sarhad Journal of Agriculture, 23(4): 1279-1284.

Salami, P., Ahmadi, H., Keyhani, A., Mohammad, S. M. (2010). Strawberry post-harvest energy losses in Iran. Researcher, 2(4): 67-73.

Sani, M.Y. and Alao, S.E. L. (2006). Assessment of Post-harvest fungi of Tomato and Pepper in selected Irrigation areas of Kano State. Nigeria International Journal of Research in Bioscience p. 53-56.

Sargent, S. A., Ritenour, M. A. and Brecht, J. K. (2000). Handling, cooling and sanitation techniques for maintaining postharvest quality. HS719. Horticultural Sciences Department, Florida.

SATNET (2014). Post-harvest Technology and Marketing Systems for Small-Scale Farmers. 10-14 March, 2014 , Royal University of Agriculture, Cambodia, Training Report. AGRA

Saxena, K.N., Pala-Okeyo, A., Seshu-Reddy, K.V., Omolo, E.O.and Ngode, L.(1990). Insect pest management and socio-economic circumstances of small-scale farmers for food crop production in western Kenya: a case study. Insect Sci. Appl. 10, 443-462.

Science Daily (2015). Waiting to Harvest after a Rain Enhances Food Security. www.sciencedaily.com (Accessed 30/5/2018)

Seid, H. Hassen, B. and Yitbarek, W.H.(2013). Postharvest Loss Assessment of Commercial Horticultural Crops in South Wollo, Ethiopia "Challenges and Opportunities". Food Science and Quality Management , 17: 34-39.

Sharma, R.R., Singh, D. and Singh, R., (2009). Biological control of postharvest diseases of fruits and vegetables by microbial antagonists: A review, Biological Control, 50: 205-221.

Silva, E. (2008). In Wholesome Success: A Farmer's Guide to Selling, Post-harvest Handling, and Packing Produce (Middle West Edition). http:// www.familyfarmed.org/retail.html (Accessed 12th April, 2018)

Singh, V., Hedayetullah, M., Zaman, P., and Meher, J. (2014). Postharvest technology of fruits and vegetables: An overview. Journal of Post-Harvest Technology, 2, 124-135.

Sirivatanapa, S.(2006). Packaging and transportation of fruits and vegetables for better marketing. In: Rolle, R.S. (Ed.), Postharvest Management of Fruit and Vegetables in the Asia-Pacific Region.

Sommer, N.F. (1985), Strategies for control of post-harvest disease of selected commodities. In: Post-harvest Technology of Horticultural Crops. University of California Press. 83-98p.

Sparks, S. A. (2013). Post-harvest Handling Systems for Fresh Fruits and Vegetables in Sub-Saharan Africa and Potential Enhancement by the Aid for Trade Initiative. Master of Science Thesis, Athens: University of Georgia

Sudheer, K.P. and Indira, V. (2007). Postharvest technology of horticultural crops. Horticulture Science Series, Pp. 1. New India Publishing.

Tadesse, F. (1991). Post-harvest losses of fruits and vegetables in horticultural state farms. Acta Horticulturae, 270, 261-270.

Toivonen, P.M.A. (2011). Postharvest physiology of vegetables. In: Hui YH, Sinha N, Ahmed J, Evranuz EÖ, Siddiq M (eds) Handbook of vegetables and vegetable processing. Wiley- Blackwell Publishing, Ames, pp 199-220. ISBN 978-0-8138-1541-1

Toivonen, P.M.A. and Hodges, D.M. (2011). Abiotic stress in harvested fruits and vegetables. In: Shanker AK, Venkateswarlu B (eds) Abiotic stress in plants - mechanisms and adaptations. InTech Europe, pp 39-58. ISBN 978-953-307-394-1

Ukech, J.A., Chiejina, N.V. (2012). Preliminary investigations of the cause of postharvest fungal rot of tomato. IOSR J Pharm Biol Sci.;4(5):36-9. 
Victor, K. (2014). Post-harvest losses and strategies to reduce them. Technical paper on Post Harvest Losses. Action Contre la Faim (ACF), member of ACF International. pp. 2-25.

Wand, S.J.E., Theron, K.I., Ackerman, J. and Marais, S. (2005). Harvest and postharvest apple fruit quality following applications of kaolin particle film in South African orchards. Scientia Horticulturae, 107, 271276.

Ward, A.R, and Jeffries, D.J. (2000). A manual for assessing post-harvest fisheries losses. DFID Projects R5027 Post-harvest fisheries research Programme.

Wei, S., Woods, E., Adar, D. and Singgih, S., (2001). West Timor mandarin marketing case study implications for supply-chain management in developing countries. In: O’Hare, T., Bagshaw, J., Li, W., Johnson, G.I. (Eds.), Postharvest Handling of Fresh Vegetables. Proceedings of a Workshop Held in Beijing, People's Republic of China, 9-11 May 2001. ACIAR Proceedings No. 105, p. 126.

Weinberger, K. and Lumpkin, T. A. (2007). Diversification into horticulture and poverty reduction: a research agenda. World Development 2007, 35, 8:1464-1480.

Wiersinga, R. and de Jager, A. (2009). In: Business Opportunities in the Ethiopian Fruit and Vegetable Sector. Wageningen University and Research Centre - LEI, p. 46.

Wilson, L.G., Boyette, M.D. and Estes, G.A. (1995). Post harvest handling and cooling of fresh fruits, vegetables and flowers for small farms leaflets $800-804$. North Carolina cooperative extension service. $17 \mathrm{p}$.

WRAP (2008). Helping Consumers Reduce Fruit and Vegetable Waste: Final Report. Available at:http://www.wrap.org.uk/sites/files/wrap/WRAP\%20RTL044001\%20Final\%20report.pdf .

Yahaya, S.M. (2005). Contribution of harvest to pathogenic and non-pathogenic losses of vegetables grown in Kano State- Nigeria. Bayero University, Kano.

Yohannes, A. (1989). Economics of horticultural production in Ethiopia: first international symposium on horticultural economics in developing countries. Acta Hortic. 16, 15-19.

$70-72$.

Zenebe, W., Ali, M., Derbew, B., Zekarias, S. and Adam, B. (2015) Assessment of Banana Postharvest Handling Practices and Losses in Ethiopia. Journal of Biology, Agriculture and Healthcare, 5(17).

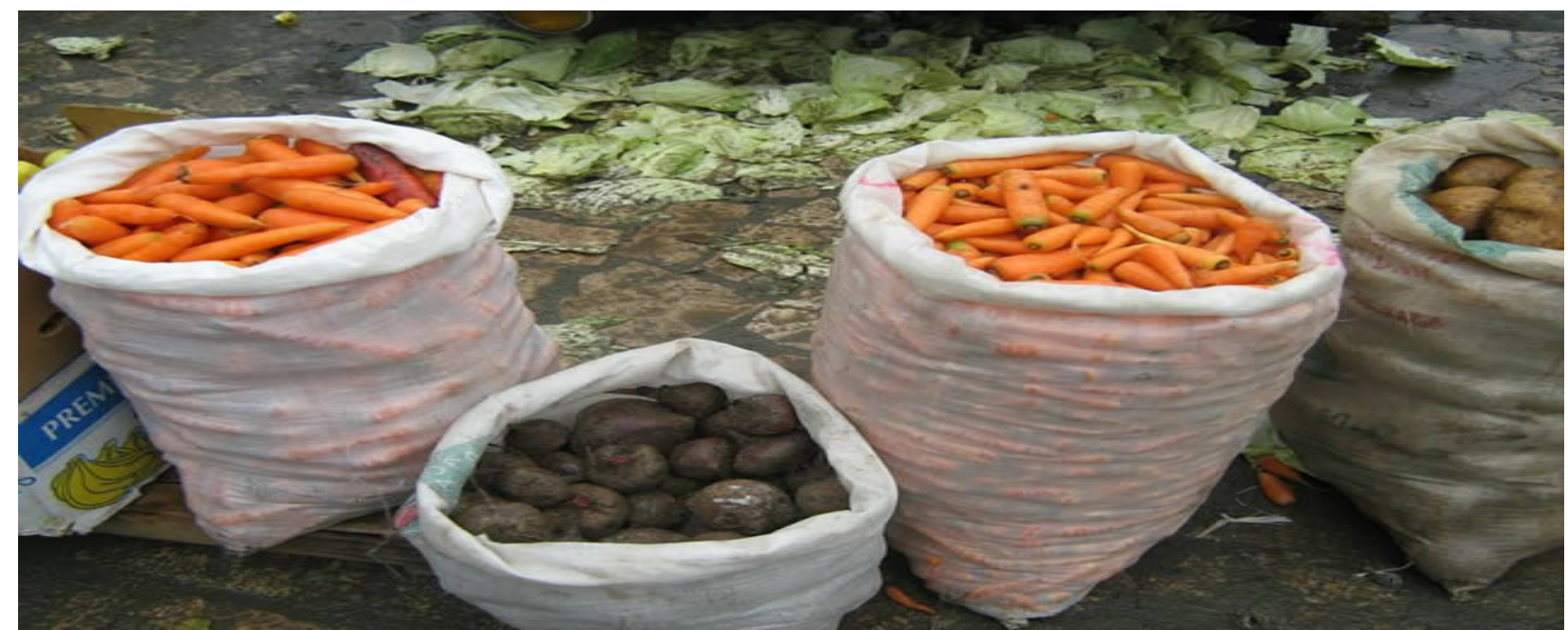

Figure1. Inappropriate packaging

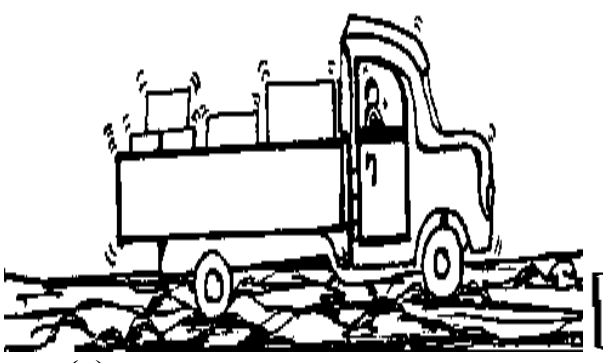

(a)

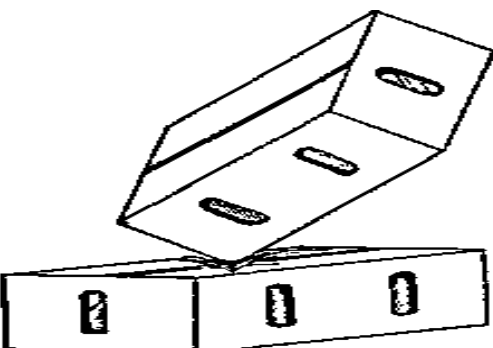

(b)

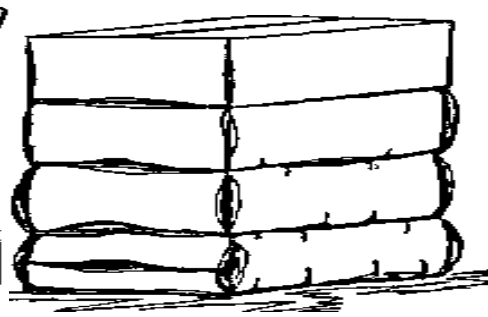

(c)

Figure 2. Mechanical injury (Abrasion, puncturing and compression injuries respectively) 


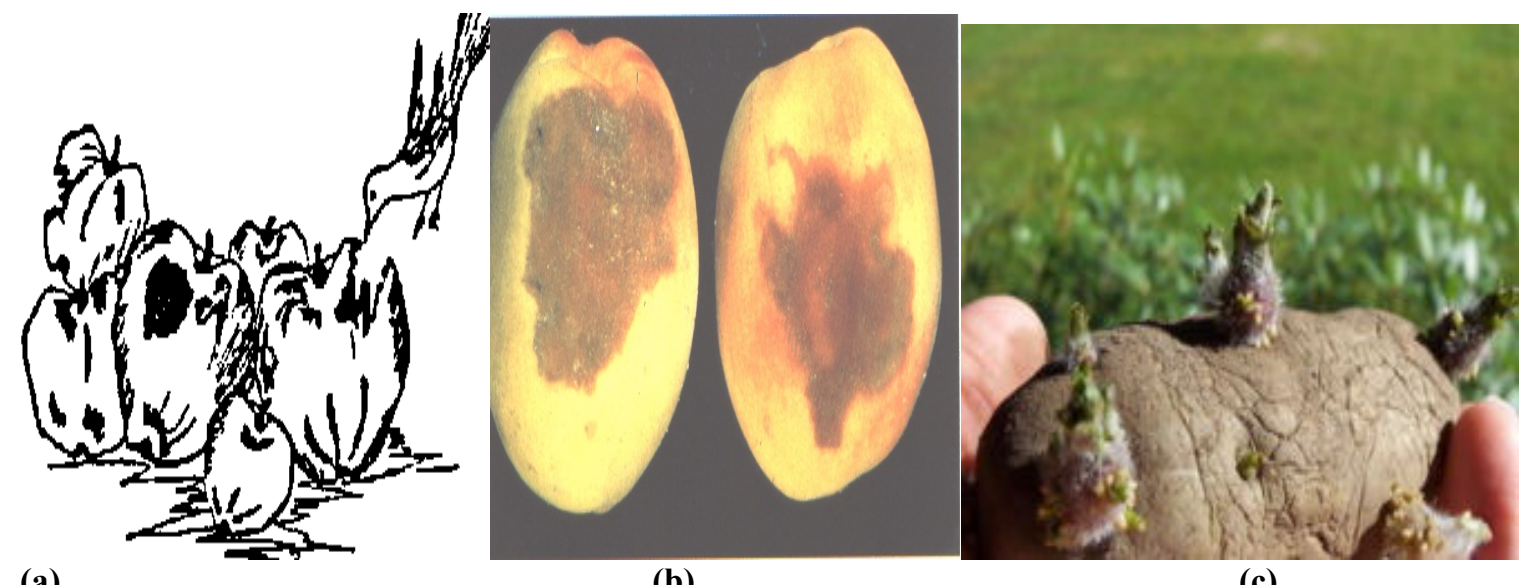

(a)

(b)

(c)

Figure 3. (Biological and microbiological, chemical and physiological losses respectively) 